NBER WORKING PAPER SERIES

\title{
QUID PRO QUO: TECHNOLOGY CAPITAL TRANSFERS FOR MARKET ACCESS IN CHINA
}

\author{
Thomas J. Holmes \\ Ellen R. McGrattan \\ Edward C. Prescott \\ Working Paper 19249 \\ http://www.nber.org/papers/w19249
}

\author{
NATIONAL BUREAU OF ECONOMIC RESEARCH \\ 1050 Massachusetts Avenue \\ Cambridge, MA 02138 \\ July 2013
}

This paper is a major revision of an earlier draft entitled "Technology Capital Transfer." All materials are available at our website at www.minneapolisfed.org/research/sr/sr486.html, including the data on all Chinese patents. We thank Andy Atkeson, Dave Backus, Nick Bloom, Ariel Burstein, Galina Hale, Patrick Kehoe, Peter Klenow, Sam Kortum, Finn Kydland, Robert Lucas, Monika Piazzesi, Natalia Ramondo, Veronica Rappaport, Kim Ruhl, Martin Schneider, Kjetil Storesletten, Fabrizio Zilibotti and seminar participants at Arizona State University, the Econometric Society, the Federal Reserve Bank of Atlanta, the Federal Reserve Bank of Minneapolis, the National Bureau of Economic Research, Simon Fraser University, the Society for Economic Dynamics, Stanford, Sveriges Riksbank, University of British Columbia, University of College London, University of Santa Barbara, University of Washington, and Universidad Torcuato Di Tella for helpful comments on earlier drafts of the paper. We also thank Andrea Waddle for excellent research assistance and Jing Fang for his help with the Chinese patent data. The views expressed herein are those of the authors and not necessarily those of the Federal Reserve Bank of Minneapolis, the Federal Reserve System, or the National Bureau of Economic Research.

NBER working papers are circulated for discussion and comment purposes. They have not been peerreviewed or been subject to the review by the NBER Board of Directors that accompanies official NBER publications.

(C) 2013 by Thomas J. Holmes, Ellen R. McGrattan, and Edward C. Prescott. All rights reserved. Short sections of text, not to exceed two paragraphs, may be quoted without explicit permission provided that full credit, including $(\mathcal{C}$ notice, is given to the source. 
Quid Pro Quo: Technology Capital Transfers for Market Access in China

Thomas J. Holmes, Ellen R. McGrattan, and Edward C. Prescott

NBER Working Paper No. 19249

July 2013, Revised November 2013

JEL No. F23,F41,O33,O34

\begin{abstract}
Despite the recent rapid development and greater openness of China's economy, FDI flows between China and technologically advanced countries are relatively small in both directions. We assess global capital flows in light of China's quid pro quo policy of exchanging market access for transfers of technology capital - accumulated know-how such as research and development (R\&D) that can be used in multiple production locations. We first provide empirical evidence of this policy and then incorporate it into a multicountry dynamic general equilibrium model. This extension leads to a significantly better fit of the model to data. We also find large welfare gains for China - and welfare losses for its FDI partnersfrom quid pro quo.
\end{abstract}

Thomas J. Holmes

Department of Economics

University of Minnesota

4-101 Hanson Hall

1925 Fourth Street South

Minneapolis, MN 55455

and The Federal Reserve Bank of Minneapolis

and also NBER

holmes@umn.edu

Ellen R. McGrattan

Research Department

Federal Reserve Bank of Minneapolis

90 Hennepin Avenue

Minneapolis, MN 55480

and NBER

erm@mcgrattan.mpls.frb.fed.us
Edward C. Prescott

Arizona State University

Economics Department

P. O. Box 879801

Tempe, AZ 85287-9801

and Arizona State University

and also NBER

edward.prescott@asu.edu

An online appendix is available at:

http://www.nber.org/data-appendix/w19249 


\section{Introduction}

Over the past two decades, China has grown rapidly and become a major destination for foreign direct investment (FDI). Surprisingly, however, relatively little of China's FDI inflows come from the technologically advanced, dominant players in global investment such as the United States, Europe, and Japan, and little of China's FDI outflows goes to these advanced countries (see Prasad and Wei 2007 and Branstetter and Foley 2010). In this paper, we assess these seemingly puzzling bilateral flows in light of China's quid pro quo policy - a policy that makes technology transfer a precondition of foreign firms selling in China. First, using surveys of foreign multinationals operating in China, we document the existence of quid pro quo policy. We then use microevidence from Chinese patents to analyze the terms of the technology transfer deals. Finally, we incorporate quid pro quo policy into a multicountry dynamic general equilibrium model and show that the policy greatly enhances the model's ability to match observations from the international accounts. We use this extended model to quantify the impact that China's quid pro quo policy has had on global innovation, growth, and welfare.

A number of authors have previously documented that FDI flows into China from advanced countries like the United States are relatively small. For example, Branstetter and Foley (2010) argue that inflows from the United States into China are small relative to flows of U.S. FDI to other destination countries, as well as relative to other source countries of investment into China. A potential explanation for this puzzle is that investment from other source countries investing in China is actually Chinese investment, which is sent to and from China's provinces in order to take advantage of policy incentives for FDI or sent to and from Caribbean islands in order to take advantage of tax-minimizing schemes. However, even when we combine flows for China and its provinces of Hong Kong, Taiwan, and Macao - netting out intraprovincial flows - and exclude flows from the tax havens such as the British Virgin Islands (BVI) and the Cayman Islands, we still find that inflows from the United States are modest and decreasing as a share over time. If we additionally include countries in Europe and Japan, we find that the share of China's inward FDI from these advanced countries falls from roughly 70 percent in 1990 to less than 30 percent in 2010. This finding is puzzling given that multinationals in technologically advanced countries have already invested in and accumulated know-how, such as R\&D capital, that can be used nonrivalrously in locations abroad, and China has promoted itself as an attractive destination for this capital.

FDI flows from China to the advanced economies of the United States, Europe, and Japan 
are also relatively small as a share of total outflows from China, even if we net out flows to and from China's provinces and the Caribbean islands. These negligible outflows are puzzling in light of the explosion of patenting in China. Prior to 1985, the patent system in China did not even exist, but its scale is now comparable to the systems in the United States, Europe, and Japan. ${ }^{1}$ Increasingly, the large and growing volume of patents in China are going to domestic applicants. Between 2000 and 2010, the domestic share of published patents in China increased from 37 percent to 73 percent. The extensive innovative activity that occurs in the United States, Europe, and Japan has led these economies to be important sources of global FDI flows, and multinationals in these economies take ideas patented at home to countries abroad, generating large FDI outflows in the process. Yet, despite all of the new patenting at home by the Chinese, FDI outflows from China to the United States, Europe, and Japan remain small.

The Chinese FDI flows are also puzzling from the perspective of the multicountry dynamic general equilibrium model developed in McGrattan and Prescott (2009, 2010), even though the model does well in accounting for capital flows to and from the United States. McGrattan and Prescott's (hereafter, MP) framework puts the Arrow-Debreu model of perfect competition to work in analyzing foreign direct investment. The key concept of the framework is technology capital. Technology capital is nonrivalrous capital that can be used across locations, so that once a firm makes an investment in technology capital in its home country, it can take the capital to other markets around the world as countries open up to FDI inflows. Examples of technology capital include accumulated know-how from investments in R\&D, brands, and organizations that are not plant specific. According to the MP model, if technologically advanced economies have accumulated large stocks of technology capital, their multinationals have strong incentives to take this capital abroad to large and growing economies such as China as these economies open up to FDI. As China is now relatively open to FDI, predictions of the MP model grossly overstate the FDI inflows to China from the advanced countries. Regarding outflows, the rapid growth in China's economy leads the model to predict the accumulation of increasingly large stocks of technology capital by Chinese firms, especially if FDI inflows from advanced countries are small and domestic firms have to make the investments themselves. This leads to the counterfactual prediction of high FDI outflows from China, both in the aggregate and to the advanced countries.

When quid pro quo is added to the MP environment, the extended model better accounts

1 In 2011, the patent office in China granted 172,000 patents, compared with 225,000, 98,000, and 238,000 patents granted by the offices in the United States, Europe, and Japan (the Europe statistic combines the European patent office with the offices in Germany, Italy, France, and the United Kingdom). See World Intellectual Property Organization (WIPO), 2012. 
for the magnitudes of FDI flows to and from China over the period 1990-2010. Quid pro quo is effectively a tax, which foreign firms pay in units of technology capital, for the right to sell in China. The model allows foreign firms to choose how much technology capital to take to China. Since the United States, Europe, and Japan are the world technological leaders, the burden of the tax falls disproportionately on them. This tax effect is a direct channel for reducing FDI inflows from advanced countries at a point in time. There is a second channel arising from the cumulative nature of technology capital transfer. While small at any point in time, transfers accumulate over time and, over the course of the sample period, a significant volume of technology capital is eventually transferred. As the advanced countries no longer own the transferred technology capital, the tangible capital investments associated with its deployment will no longer be counted as FDI from the advanced countries and thus FDI inflows are lower. When considering outflows from China, what matters is the terms of the quid pro quo arrangements. We document that transferred property rights apply inside China, not outside. In effect, there is an intellectual property wall that prevents Chinese firms from taking the transferred capital outside China, and therefore we do not see the FDI outflows that would otherwise take place if ownership of transferred capital extended outside of China.

Ample evidence supports the key mechanisms of the model. Prior to 2002, when China joined the World Trade Organization (WTO), quid pro quo transfer of technology was explicit Chinese policy. Since then, the policy has become implicit and is accomplished through requirements such as joint ventures. Surveys of multinationals we cite below confirm that that quid pro quo is an implicit policy and a majority of respondents say that requirements are increasing over time. Furthermore, microevidence from patent data support a key mechanism of the model; the data show that as part of the quid pro quo arrangement, the property rights transferred apply inside China, not outside. To demonstrate this, we construct a unique data set of Chinese patents - with foreign and domestic patents separately catalogued - and we use it to determine which patents go outside China in the form of patents in other countries. We focus in particular on patents in China that are jointly owned by a foreign multinational and a local Chinese partner. These come out of the various joint ventures that foreign firms have been forced into as a requirement for market access. They are direct evidence of technology connections between foreign and domestic firms and direct evidence of Chinese firms obtaining property rights in China. We document a sharp empirical finding about these jointly-owned patents: the property rights of the Chinese partners stop at the border, exactly as assumed in our theory. An interesting example in our data set is the case of the joint venture between the foreign telecommunications giant Alcatel-Lucent and the 
domestic firm Shanghai Bell. Through 2010, 97 of the jointly owned patents in China have gone outside in the form of WIPO applications. Yet in all but five cases, the applications make explicit that Shanghai Bell shares ownership only in China and Alcatel-Lucent is the sole owner in every other country. Although this example is revealing, it turns out that the typical way that Chinese ownership stops at the border is that the jointly owned patents do not go outside of China in the first place. For example, in the case of General Motors (GM), which co-owns 70 patents with its Chinese partner Shanghai Automobile Industry Company (SAIC), none of the patents extend outside of China. What makes these cases particularly striking is that when we look by comparison at patents that are not owned via joint venture, a nonnegligible fraction of these patents do go outside China.

We use our quantitative model to conduct welfare analysis and to estimate the extent of technology capital transfer in China over the period 1990-2010. The model has six economies, namely, China and its provinces, the United States, Western Europe, Japan, an entity comprising Brazil, Russia, and India, and the rest of the world. We assume that changes in total factor productivities are such that per capita GDPs are aligned in the model and data, and we assume that policies governing capital accounts are such that total FDI inflows into the six economies are aligned in the model and data. We then compare statistics for the model with and without quid pro quo policy. ${ }^{2}$ We find that the model predictions about innovative activity and international capital flows depend critically on the inclusion of quid pro quo technology capital transfers. We also find that following a quid pro quo policy yields large welfare gains for China - on the order of 4.5 percent in annual consumption - whereas all other economies suffer welfare losses.

In addition to studying policies in China over the past two decades, we consider alternative scenarios of policies in the next two decades, both inside and outside of China. Specifically, we consider alternative scenarios for future quid pro quo policy and policies affecting growth and capital flows in different regions. We find that if quid pro quo policies are discontinued, China's investment in technology capital more than doubles by 2030. Our predictions about China's future innovative activity, however, are sensitive to assumptions about growth and capital controls in other regions and this prompts our investigation of policies outside of China. The model predicts that innovative activity is highest in regions where growth is relatively high and capital controls are relatively tight.

2 We also allow for knowledge spillovers from foreign affiliates to domestic firms, which are transfers of technology that do not directly compete with or devalue the affiliate's technology capital, but we find this factor to have a small impact on the results. 
Section 2 discusses the related literature. Section 3 presents evidence in support of the key mechanisms in our model. Section 4 describes the multicountry general equilibrium model used in our analysis. Section 5 is an application of the theory that uses data for China and its main FDI partners. Section 6 explores future predictions for China's economy, and Section 7 summarizes and concludes.

\section{Related Literature}

Much of the literature on FDI focuses on the margin of whether a particular firm sells in a foreign market through exports or by setting up a foreign affiliate (see Horstmann and Markusen 1992; Markusen and Venables 2000; Helpman, Melitz, and Yeaple 2004; and Ramondo and RodríguezClare 2013). Taking into account that consumption goods come in different varieties is essential in these analyses, because this differentiation motivates exports and imports of goods between countries, that is, wool for wine. In contrast, our model has only a single consumption good and the main force for aggregate trade flows is imperfectly correlated total factor productivities (as in Backus, Kehoe, and Kydland 1992). Our emphasis is on companies using FDI to sell to local consumers, not as an export base. Each unit of technology capital has a potential use in production at each location; to realize the potential use, the capital must be deployed locally. Although in general there are important connections between FDI and trade, we believe that abstracting from trade in differentiated consumption goods in the context of this study is useful for two main reasons. First, the entry regulations for selling in the domestic market (ordinary trade) are more stringent - and quid pro quo policy has more bite here - than the regulations for selling only in export markets (processing trade). ${ }^{3}$ These differences are not surprising because the Chinese government has a monopoly over access to its domestic market, whereas it might face competition with other countries to be an export base to other markets. Second, FDI aimed at the local market is a significant component of the FDI going into China. ${ }^{4}$ For example, the automobile industry is one of the major industries with inflows into China from the United States, Europe, and Japan. The joint ventures that are set up as part of these inflows sell primarily to the domestic market.

An enormous empirical literature examines the extent to which knowledge spillovers from

\footnotetext{
3 For example, in 1986 China adopted a policy where foreign firms selling only to export markets could enter as a wholly foreign-owned enterprise, rather than through a forced joint venture. See Branstetter and Lardy (2006).

4 See Branstetter and Foley (2010) and Defever and Riaño (2012), who show that most of the foreign firms using China as an export base are from Taiwan and Hong Kong.
} 
multinational investment flow to domestic companies in host nations. Typically, these studies regress measures of productivity of local companies on some measure of geographic proximity of FDI. Hale and Long $(2011,2012)$ survey the literature that focuses on China and contribute to it by studying firm-level data from a World Bank survey, finding mixed results. The standard approach to modeling knowledge spillovers is to treat them as an externality. Productivity is higher when more firms invest, but since any one firm is a small part of the total, firms do not take into account the spillovers in their investment decisions. In our baseline model, we allow for the presence of such spillovers but also consider a specification where the spillovers are shut down, and in this way, we recognize the mixed results in the literature. Regarding the model's ability to fit FDI flows and a number of other variables, whether we allow for spillovers turns out not to matter much. In contrast, allowing for the quid pro quo mechanism has a significant effect on FDI flows. The key difference is that with quid quo pro, a firm internalizes the effective tax on entry when doing FDI. With spillovers, the effect is external, limiting the scope for the spillover channel to influence the FDI decisions. ${ }^{5}$

One example from the literature that takes a quantitative theoretical approach, as we do here, is the model of international technology diffusion in Eaton and Kortum (1999). They trace how ideas patented in one country diffuse abroad as patents in other countries. Our analysis of whether Chinese patents go outside China is in keeping with the spirit of their work. Our work differs from theirs, however, in at least four ways. First, although their structure allows for imitation, it does not incorporate the quid quo pro mechanism that is central here. Second, we focus on the transition dynamics of knowledge transfer between developed countries and developing countries, such as the United States and China, whereas Eaton and Kortum (1999) explore a steady-state relationship between developed countries, such as the United States and Germany. Third, in addition to looking at patent statistics, we focus on data on FDI flows. Fourth, our modeling environment with perfectly competitive firms is different from the structure of Bertrand oligopoly they use (which is based on Grossman and Helpman 1991a). Our use of perfect competition makes it computationally tractable to consider a rich structure and to calculate transitional dynamics.

An earlier literature emphasizes the trade-off between the benefits of greater FDI and the costs of diminishing the value of intellectual property holdings. Theoretical contributions to this literature include Grossman and Helpman (1991b) and Helpman (1993), who study growth models

5 Note that since intangible investments are not included in GDP, measured productivity in our model is not the same as true productivity, and therefore results of productivity regressions with data from our model could be be misleading. 
with two regions - North and South - with the South imitating products from the North. Lai (1998) extends these models to allow the degree of imitation to be a function of whether the firm engages in FDI in the South (see also Markusen 2001). In these papers, the benefit to the North is lower production costs, which is different from the benefit of market access that we focus on here. Also, some empirical work finds that imitation is a deterrent to FDI. For example, Branstetter et al. (2011) present regression evidence that multinational companies increase their FDI after host nations strengthen their intellectual property protection.

This paper highlights as a puzzle the relatively low investment flows between China and the technologically advanced economies and, in particular, the fact that flows from advance countries have been falling in recent years in a relative sense. An existing literature considers frictions that limit FDI flows between pairs of countries due to characteristics specific to the pair, such as differences in language and geographic distance. (Recent examples are Keller and Yeaple 2013, and Ramondo Rodriguez-Clare 2013.) In our robustness analysis we consider a version of the model without quid pro quo, but including an additional friction limiting FDI flows between countries in the west such as the United States and Western Europe and countries in the east such as China. The friction depresses the levels of inflows and outflows. However, since frictions like language differences and geographic distance are constant over time, this alternative model without quid pro quo can not account for why inflows from advanced countries are falling over time in a relative sense.

Fajgelbaum, Grossman, and Helpman (2011) propose the Linder hypothesis as an alternative explanation for the relatively low investment flows between China and the technologically advanced economies, but this theory also has counterfactual predictions for the time paths of FDI flows. The idea behind the Linder hypothesis is that countries with similar incomes are more likely to be FDI partners, as compared to countries with different incomes, because they share similar consumption patterns. For example, a rich country like Germany will tend to make luxury cars - such as BMWs and Mercedes - which are sold by their affiliates in rich countries like the United States, rather than in poor countries like India where the world's lowest-priced car is made (the $\$ 3,000$ Tata Nano). In the theory, differences in income turn out to be similar to differences in language and geographic distance in creating effective barriers to FDI flows. If we apply the Linder hypothesis to the case of FDI between China and the advanced economies, we find that it implies counterfactually that the relative share of FDI inflows from the advanced (rich) countries into China should be increasing as China is moving up the income ladder, contrary to what we see in the data. 
Finally, although we use theory to indirectly measure investments that are not counted in China's national accounts, such as R\&D and investment in brands, some recent work attempts to directly measure these investments. Hulten and Hao (2012) estimate that intangible investments in China was 7.5 percent of GDP in 2006, although they acknowledge that the exercise is "greatly hampered by the uncertainty about the accuracy of the data." Furthermore, considerable debate surrounds the source of the intangible investments - that is, whether the government is the source of the spending in order to meet its goals for technological advancement or whether firms are choosing to make the investments themselves (see Hao 2012). Here, we use a theoretical framework, which is parameterized in such a way as to be consistent with measured statistics in the national and international accounts, to indirectly infer the intangible investment in China and elsewhere. ${ }^{6}$

\section{Evidence for the Mechanisms}

In this section, we present evidence for the key mechanisms we will introduce into our model. First, we document the existence of the quid pro quo trade-off that foreign firms face in China, namely, technology capital in exchange for market access. Second, we provide evidence that the rights being traded are for rights inside China, not outside. Third, we provide evidence that the United States, Europe, and Japan are the technological leaders and, as such, have more to offer in quid pro quo arrangements and more to lose when they increase FDI in China. Finally, we relate the evidence to the key puzzles cited in the introduction concerning the FDI flows in and out of China over the period 1990-2010.

\subsection{Quid Pro Quo: Technology Capital Transfer for Market Access}

We start by documenting that access to China's market for multinational firms in high technology industries comes at the price of technology transfer. Prior to China's 2002 accession to the WTO, quid pro quo was explicit policy. For example, in 1994, China's State Planning Commission introduced a policy initiative detailing specific technology transfer requirements for foreign firms wishing to enter the domestic automobile market. All foreign investment had to be in the form of a joint venture with a domestic partner. The policy initiative contained a technology threshold in that the enterprise was required to have "the capacity for manufacturing products which attain

6 In recent work, Ramondo, Rappaport, and Ruhl (2012) study intrafirm trade of U.S. multinationals and provide evidence consistent with the view that a primary motivation for FDI is the transfer of intangible inputs-rather than tangible inputs - across production units. 
the international technological levels of the 1990s."7 Furthermore, the policy required that "an office responsible for technological research and development must be set up within the enterprise" (Walsh 1999, 47). Under the terms of accession to the WTO, technology transfer requirements for market access are not permitted, and the Chinese government is generally careful not to make explicit statements about quid pro quo. ${ }^{8}$ Nevertheless, the widely held view - in government reports and throughout the business community - is that China continues to impose technology transfer requirements as an implicit policy. ${ }^{9}$ Maintenance of this policy is consistent with official Chinese government pronouncements that a key policy goal is "indigenous" or "self-owned" innovation. ${ }^{10}$

Firms are generally reluctant to go on the record about technology transfer requirements because of confidentiality issues and fear of retaliation by the Chinese government (see Shea 2012). Therefore, examining the results of recent confidential surveys is useful. In its 2012 survey of members, the U.S.-China Business Council - a trade group made up of 230 large U.S. firms with significant business interests in China - found that " 85 percent of companies report that they are at least somewhat concerned about transferring technology to China" and "36 percent of respondents indicated they were asked in the past three years to make such a transfer as a requirement for gaining an investment, project, product or market entry approval" (U.S.-China Business Council 2012a, 2012b). These findings are corroborated in another recent survey by the American Chamber of Commerce in China (AmCham China 2013). In the survey, 35 percent answered positively to the question "Is de facto technology transfer as a requirement for market access in China a concern for you?" Moreover, a majority of those responding indicated these requirements were increasing over time rather than decreasing. ${ }^{11}$ These survey findings are inconsistent with the notion that quid pro quo is a thing of the past now that China is part of the WTO. ${ }^{12}$

Maintaining a quid pro quo policy is feasible for China because it has mechanisms in place that

7 The policy paper was published under the title "Automotive Industry Industrial Policy" (see Walsh 1999, Table 17). See also U.S. Congress (1987) for a discussion of earlier Chinese policies on technology transfer.

8 Paragraph 7.3 of the 2001 China accession protocol states, "China shall insure...investment...is not conditioned on...the transfer of technology" (see WTO 2001).

9 For the U.S. government, see, in particular, United States International Trade Commission (USITC 2010). For Europe, see the European Commission's (2011) how-to guide for investing in China, which matter-of-factly notes that "over the years, gaining market access in exchange for bringing foreign technology to China has been a successful bargain for many European companies."

10 The plan, which is laid out in China State Council (2006), states China's goal for zizhu chuangxin; zizhu means "indigenous" or "self-owned," and chuangxin means "innovation." See the discussion in USITC (2010).

11 Excluding nonresponses and "Don't know," 57 percent chose "Increasing," 38 percent chose "Staying the same," and only 5 percent chose "Decreasing."

12 Recent research shows that these forced technology transfer deals actually work as intended, namely, they upgrade the domestic partner. Van Reenen and Yueh (2012), for example, provide evidence that the partner's total factor productivity (TFP) increases after such deals. 
enforce technology transfer. In particular, China continues to impose joint venture requirements in priority industries. Moreover, joint venture contracts require approval by government officials, and these officials retain significant discretion in approval decisions (see Shea 2012). The main policy document regulating entry of foreign firms into China, first introduced in 1995, has categories with specific notations about joint ventures (see China Ministry of Commerce 2007). For example, under item 19, "manufacturing of complete automobiles," is the note "foreign investment shall not exceed 50 percent."

In the case of electric engines and batteries, an area where many important advances in the automotive industry are currently taking place, the Chinese government has set up an explicit quid pro quo policy that appears on its face to be a violation of the WTO protocol. The government is offering subsidies for new technology electric vehicles, but foreign firms qualify only if they transfer one of three key technologies to a joint venture domestic partner. An official at Ford Motor said the company planned to transfer technology in order to obtain market access on the same terms as domestic Chinese firms. ${ }^{13}$ Other companies, such as Nissan, said they would not participate because they felt the quid pro quo terms were too onerous.

\subsection{Terms of the Deal: Property Rights Inside China, Not Outside}

In principle, one can imagine a deal where a foreign multinational obtains access to China's market in exchange for a particular set of technology capital property rights that apply throughout the world. Although China has the ambition to own technology capital with global reach, and although leakage may occur outside China in FDI technology transfer deals, our hypothesis is that the property rights being exchanged in market access deals are primarily rights inside China, not outside. Here, we present evidence from patent data that is consistent with this hypothesis. We examine initial ownership of new patents by large multinational firms doing FDI in China. We show that although these firms may jointly hold patents with domestic partners inside China, shared ownership effectively stops at the border.

Ideally, we would analyze the licensing terms of existing patents, which is the primary channel for technology transfer (see, for example, discussions in U.S.-China Business Council 2012a, 2012b and European Commission 2011). We focus on initial ownership of new patents, because this information is publicly available in the published patent data, whereas licensing terms are generally confidential. The published data are informative, however, because technology transfer

13 See Keith Bradsher, "Hybrid in a Trade Squeeze," New York Times, September 5, 2011. 
deals potentially lead to new patents through two channels. First, Chinese contract law creates certain default rights to firms' licensing technology, specifically the ability to claim property rights for subsequent innovations, and these rights connect technology transfer deals in China with subsequent innovations and patents (see Article 335 of China Supreme People's Court 1999). Second, the contract may involve creation of a joint venture R\&D center, such as those mandated by the automobile industry regulation discussed earlier, and we can expect jointly owned patents to result from these joint ventures.

To construct our sample of multinationals, we begin with data for foreign affiliate sales, provided by China's Ministry of Commerce, for the top 500 foreign affiliates in 2007 as ranked by domestic sales in China. After consolidating business units of the same firms and excluding firms from Taiwan, we are left with a list of 114 large foreign multinationals; these firms have total sales of $\$ 314$ billion in 2007. ${ }^{14}$ Joint ventures are significant in the data. In fact, almost half of the affiliate sales in the data are in business units where the affiliate name includes a Chinese partner as well as the foreign multinational.

For this sample, we examine data on patent applications in China for the years 2005-2010 and focus on patents that are classified as the invention type. ${ }^{15}$ The data are patent applications that have reached the publication phase. ${ }^{16}$ We examine the text field of the applicant name and determine which patents include the names of the 114 large foreign multinationals. We then classify a patent as "Shared with Chinese partners" if $(i)$ a Chinese firm is also listed as owning the patent or $($ ii) the business unit listed on the patent is one where a Chinese firm has an ownership stake, based on a search of company documents and news reports. Otherwise, we classify the patent as "Not shared." Across the 2005-2010 sample period, 10,184 patents owned by the foreign multinationals are shared with a Chinese partner and 199,410 are not shared, as reported in the top part of Panel A in Table 1.

The shared patents speak to both the assignment of property rights in China to Chinese firms and to a link with the technology of foreign multinationals. Our interest here is whether the property rights of the Chinese firms in China extend outside China. Specifically, we ask two questions. First, do the patents themselves link outside China? We measure this by determining

\footnotetext{
14 The sample includes 34 U.S.-based firms with total sales of $\$ 73$ billion. See Holmes, McGrattan, and Prescott (2013a) for further details about the construction of the data set.

15 Utility patents require a lower inventive threshold, but since they are of negligible importance for foreign firms, we exclude them.

16 Publication of a patent application is an intermediate stage between the application for a patent and the grant of a patent. Some applications are withdrawn before the publication stage.
} 
whether the same patent in China has also been filed as either a U.S. patent application or a WIPO application. ${ }^{17}$ Second, in cases where patents link outside, are the Chinese firms included in the owner list on the outside applications?

Regarding the first question, Table 1 reports that the fraction of shared patents linked outside China is quite low, only 1.7 percent. As for the second question, we have examined the applicant name fields of the 177 patents that make up the 1.7 percent with links to U.S. or WIPO applications. Of these, there are 21 instances where the Chinese firm is listed on the outside application. In summary, for only 21 out of 10,184 shared patents, or 0.2 percent, does Chinese ownership of shared technology with foreign multinationals extend outside the Chinese border.

To put these findings in perspective, it is useful to examine the extent to which other Chinese patents link outside. Most foreign-owned patents in China are filed first in foreign countries (typically in the country where the inventive activity takes place), and afterward brought into China through a filing in the Chinese patent office. Patents that start outside, and come in, obviously link outside. We can see in Table 1 that 86 percent of unshared, foreign patents link outside. To make comparisons more direct, we focus on patents in China filed first in China. Virtually all of the shared patents are filed first in China. We examine whether a patent subsequently goes outside, after an initial filing in China.

We first compare the shared patents with unshared patents owned by Chinese firms. To construct the latter set, we begin with patents first filed in China, and then we remove any remaining patents of large multinational firms, as well as patents of academic institutions. ${ }^{18} \mathrm{We}$ can see in Table 1 that 4.7 percent of unshared, Chinese firm patents subsequently go outside China. Note that the set of Chinese firm applicants as a whole includes many small firms. To obtain a group of Chinese applicants that is more comparable in size to our sample of 114 large foreign multinational firms, we select the top 100 Chinese applicants by counts of patents. We find that 16.5 percent of patents of large Chinese patenters subsequently go outside. Note the sharp differences here. On the one hand, if a Chinese firm has its name on a patent that is not shared with a foreign multinational, then 4.7 percent of the time it has its name on a corresponding patent outside of China, with the rate equal to 16.5 percent if the firm is a large patenter. On the other hand, if the patent is shared, the probability drops to 0.2 percent.

Next we look at the patents of our sample of large foreign multinationals that are first filed

17 A WIPO application standardizes the process of applying for patent protection in multiple countries.

18 We also manually process large patenters to eliminate patents where the applicants are individuals rather than firms. 
in China and not shared with a Chinese partner. There are 12,446 of these patents, and 10.1 percent subsequently go outside - about seven times higher than the rate for the shared patents. In addition to requiring the patent first be filed in China, we can further condition on whether the applicant name field specifies a Chinese subsidiary of the multinational and whether the set of inventors includes at least one with a Chinese name. In this way, we focus on technology of the foreign multinational in cases with the inventive activity likely occurring in China. The results are similar. Comparing unshared and shared patents, the rates of subsequently going outside are 10.7 and 2.0 percent, respectively.

In our previous discussion of China's policies, we noted in particular the automotive industry. Panel B of Table 1 presents results specifically for this industry. Twelve foreign multinationals produce automobiles in China, and all of them do so through joint ventures with one or more of seven major Chinese auto companies. ${ }^{19}$ The top row of Panel B in Table 1 shows that the results for foreign multinationals in the automobile industry are similar to the results for the broader set of industries. Foreign multinational patents that are shared do not go outside China; the percentage linked to U.S. or WIPO applications is only $0.7 .^{20}$

The second row in Panel B of Table 1 reports the patents in China that are owned by the seven major Chinese automakers that operate through joint venture, where ownership of the patent is not shared with a foreign firm. For example, this category includes patents that have a Chinese automaker's name on them, say, SAIC, but not the names of its foreign partners (Volkswagen and General Motors in SAIC's case). Only 936 such patents fall into this category compared with 14,500 patents owned by the foreign partners. This vast difference makes it clear that the foreign partners are the source of technology in the joint ventures. Notice that the 936 patents solely owned by the Chinese partners go outside China at a very low rate, namely, 0.9 percent.

The final row of Table 1 reports patents for the six main Chinese automakers that do not operate through a joint venture, that is, the independent automakers. ${ }^{21}$ In 2012 , the independents accounted for just under 20 percent of vehicle production and, similarly, just under 20 percent of Chinese patents in the automobile industry. Together, these firms have 3,277 patents, which is more

19 The twelve foreign companies are Toyota, Honda, Nissan, Hyundai, Ford, Volkswagen, General Motors, Mazda, Daimler, Suzuki, Peugeot Citroen, and BMW. The seven Chinese automakers that operate through joint venture are SAIC, Dongfeng, FAW, Changan, BAIC, GAC, and Brilliance. The separate appendix in Holmes, McGrattan, and Prescott (2013a) provides further details.

20 The 142 patents listed as shared in Table 1 are cases where the Chinese partner is a business, and only one such patent goes outside China. In an additional 7 cases, a foreign multinational partners with an academic institution in China, and 2 of these patents go outside of China.

21 These are Great Wall, Chery, Geely, JAC, BYD, and Lifan. We restrict attention to those automakers producing 200,000 or more units in 2012. See Holmes, McGrattan, and Prescott (2013a) for further details. 
than three times as many patents as the 936 patents owned outright by the Chinese automakers with foreign partners. The firms with foreign partners have access to the 14,500 foreign-owned patents through technology transfer agreements. The independent firms do not have technology transfer contracts and take technology outside of China at the higher rate of 7.4 percent. Many reports claim that even the independent firms obtain technology from foreign firms and we consider this possibility further in Section 5.2. ${ }^{22}$ In some sense, this practice could be thought of more broadly as quid pro quo because foreign multinationals know that China has weak IP protection and still they do some FDI there.

\subsection{Countries Are Not All Alike: Technological Leaders and Laggards}

The concept of technology capital in McGrattan and Prescott (2009, 2010) is broad, including high-tech intangible capital such as R\&D in advanced communications and electronics, and lowtech intangible capital such as brands of restaurants and hotel chains. The strategic plan laid out in China State Council (2006) for indigenous innovation is clearly aimed at high-tech capital rather than low-tech, and we expect the burden of technology transfer requirements for market access to fall more heavily on high-tech firms compared with low-tech firms. Since countries differ in the degree to which their firms tend to be high-tech, we expect technology transfer requirements to be more burdensome for some countries than others. This expectation motivates us to allow China's policy parameters to vary across countries doing FDI in China.

Historically, the United States, Europe, and Japan have been recognized as the world leaders in high-tech innovation. Table 2 presents evidence on differences in the degree of high-technology across countries. Note that in the table we use the same country groupings that we will use later in our quantitative model. Specifically, we group China with the three provinces of Hong Kong, Taiwan, and Macao; we group countries of Western Europe; we group the three large emerging economies of Brazil, Russia, and India (BRI); and we group non-Caribbean countries not elsewhere listed that had foreign direct investments in China in excess of 0.1 billion U.S. dollars in 2007 and call them rest of world $(\mathrm{ROW}){ }^{23}$

22 An example is General Motors in their suit against the Chery Automobile Company. GM claimed that the Chery QQ is a clone of GM's Chevrolet Spark. According to news reports, analysts projected that "the QQ will not be sold in the United States, owing to the G.M. litigation" (see Chris Buckley, "Enter the Chinese Dragon, Now Bearing Minicars," New York Times, January 7, 2005). See also USITC (2010) for examples in other industries.

23 Western Europe includes Austria, Belgium-Luxembourg, Denmark, Finland, France, Germany, Greece, Ireland, Italy, Netherlands, Norway, Portugal, Spain, Sweden, Switzerland, and United Kingdom. Rest of world includes Australia, Bahrain, Canada, Indonesia, Korea, Malaysia, Mauritius, Philippines, Samoa, Saudi Arabia, Singapore, and Thailand. In our benchmark model, we exclude inward FDI from Caribbean countries 
The first statistic we report in Table 2 is the triadic patent count measure developed by the Organisation for Economic Co-operation and Development (OECD), and we report these counts on a per capita basis (per million in population). ${ }^{24} \mathrm{~A}$ triadic patent is one that has been granted by each of the patent offices in the United States, the European Union, and Japan. Restricting attention to innovations that have been brought into these three main innovation markets selects the most significant innovations and addresses a home bias problem. ${ }^{25}$ The table makes it clear that the three innovation centers are the United States, Western Europe, and Japan; they are very different from the rest, with triadic patent rates of 49.1, 36.3, and 117.0, compared with only 3.5 for ROW and 0.1 for both China and BRI. ${ }^{26}$ We can use another measure of knowledge and see the same qualitative pattern. In a recent report, the National Science Foundation (NSF 2012) classifies certain industries as knowledge-intensive services and high-technology manufacturing. ${ }^{27}$ For the year 2000, we show in Table 2 that the United States leads with a 36.3 percent knowledgeand technology-intensive share of GDP, and Western Europe and Japan come in next at around 28 percent. ROW is lower at 25 percent, and China and BRI are at the bottom, around 20 percent.

Based on these facts, in our quantitative model, we will assume that China has one set of policy parameters for the high-tech countries, namely, the United States, Western Europe, and Japan, and another set of parameters for the rest of the world.

\subsection{Relating the Mechanisms to the Puzzles}

As we noted in the introduction, China has warranted significant attention over the past two decades for its rapid growth and its transition from a country manufacturing cheap toys to a country making significant inroads in its capacity to innovate in high-tech industries like semiconductors and supercomputers. The widely held belief is that an important factor underlying this transition has been the opening of China to foreign direct investment. In this section, we review the facts, highlight the puzzles, and discuss how the mechanisms described earlier yield a potential resolution to these puzzles.

because these flows are primarily related to sheltering taxes. In our sensitivity analysis, we change regional assignments by adding net inflows from the Caribbean islands and including Korea with Japan rather than with ROW.

24 See Dernis and Khan (2004) for a discussion of the methodology.

25 Inventors with relatively unimportant ideas may obtain a patent in their home country but ignore other countries. Triadic patents are for ideas that are evidently important enough to be brought to at least two outside markets.

26 Note that we use year 2000, which is the midpoint of the 1990-2010 sample period we use when assessing our quantitative model.

27 See the note to Table 2. 
We first note the rapid growth in China's income. As we show in Table 3, GDP per capita (in 2005 international dollars) increased from $\$ 1,436$ to $\$ 7,434$ over the period $1990-2010{ }^{28}$ Given China's huge population, China now accounts for a significant percentage of world income - roughly 15 percent in 2010 - making access to this market particularly important to multinational firms.

Over the same period, China's technology share has grown. Table 3 reports that China's share of $R \& D$ expenditures relative to the combined expenditures of the United States, the European Union, Japan, and China was only 1.8 percent in 1990 and increased by more than a factor of eight, to 15.5 percent, by 2010 . Regarding patents, relatively little patenting was done by either domestic firms or foreign firms in China in 1990, as the Chinese patent system was still in its infancy. By 2000, patenting by foreign firms in China began to be significant and made up a majority of newly published patents. ${ }^{29}$ In more recent years, Chinese entities have begun to dominate patent counts in Chin, with the domestic share increasing from 38.6 percent to 72.8 between 2000 and 2010. Chinese applicants filing patents outside of China also increased from negligible amounts in 1990. By 2010, Chinese applicants accounted for 5.1 percent of WIPO applications and, excluding Taiwan, 2.9 percent of U.S. patents granted that year to foreigners. While the latter is a $30-$ fold increase since 1990, it remains the case that China's patenting in the United States is small compared to China's patenting in China.

China's rapid development has occurred simultaneously with a rapid influx of foreign direct investment. This occurrence has led many to conclude that FDI has been an important factor in China's transition, because with FDI comes the transfer of foreign technological know-how. From this perspective, however, China's FDI inflows and outflows seem puzzling. In Figure 1, we plot inward FDI flows to China from all countries (except BVI and the Cayman Islands) and from the technological leaders, namely, the United States, Western Europe, and Japan, which are the dominant countries in global FDI. In fact, what the picture shows is that the share of FDI into China from these countries is actually falling over the period, while incomes and other indicators of technology are rising. Why are these countries dominant elsewhere and not China, which grew rapidly and increased its share of technology during this period? A further puzzle emerges from Figure 2, which shows outward FDI flows from China to all countries (except BVI and the Cayman Islands) and to the United States, Western Europe, and Japan. For most years, the outflows are small — both relative to outflows of advanced countries and relative to inflows to China — and the

\footnotetext{
28 When we report statistics for China here and later, the provinces of Hong Kong, Taiwan, and Macao are assumed to be included unless noted otherwise.

29 As earlier, we restrict attention to invention patents.
} 
recipients are countries other than the technological leaders. ${ }^{30}$ Why isn't the increase in technology share translating into large FDI outflows across the world?

Our answer to these questions relates back to the key mechanisms described earlier. Multinationals from the United States, Western Europe, and Japan doing FDI in China face quid pro quo transfers of technology capital for access to China's market. The more attractive China is as an FDI destination, the greater the demands for transfers and the lower the incentives for multinationals to deploy their technology capital. In other words, with quid pro quo, we should see the pattern shown in Figure 1 with respect to inward foreign direct investment, with an asymmetry between the technological leaders and the rest of the world. Similarly, we should see the pattern of Figure 2. Although less foreign capital comes in, domestic firms might find it optimal to appropriate some of that foreign capital rather than innovate themselves. If the terms of the deal are that the property rights are restricted to China, we would not expect to see sizable outward FDI flows from China, especially to countries that were the original innovators. Any indigenous innovation can leave China, and the upward trend in indicators of investments in technology capital can account for the fact that outward FDI flows have increased over time.

In the next section, we incorporate quid pro quo in a quantitative dynamic general equilibrium model. We show that incorporating quid pro quo improves predictions for global capital flows, and we then use it to quantify the impact of China's policies on innovation, growth, and welfare.

\section{Theory}

The model we use to assess the importance of technology capital transfer is an extension of McGrattan and Prescott $(2009,2010)$ that includes the quid pro quo mechanism and the choice of an intensity level with which to deploy technology capital in a particular market. We also allow for knowledge spillovers in the creation of new technology capital. We work with an aggregate production function, derived by aggregating first across plants and then across companies. The aggregate technologies are embedded in a multicountry general equilibrium model with two types of firms: multinationals that have proprietary technology capital and appropriators. Appropriators use technology capital that has been transferred to them through quid pro quo and can use it only in their local market. We use the theory to quantify the economic impact of quid pro quo policy.

30 An exceptional year is 2010, when there was an unusually large outflow of FDI from Hong Kong to Luxembourg. 


\subsection{Multinational Problem}

Consider the problem of the multinationals with proprietary technology capital. These multinationals choose the scale of overseas operations to maximize the present value of after-tax worldwide dividends,

$$
\max \sum_{t} p_{t}\left(1-\tau_{d t}\right) D_{t}^{j}
$$

where $t$ indexes time, $p_{t}$ is the Arrow-Debreu price, $\tau_{d t}$ is the tax rate on dividends, and $D^{j}$ is the aggregate dividend payment.

The aggregate dividend payment is the sum of dividends across countries $i=1, \ldots, I$,

$$
D_{t}^{j}=\sum_{i}\left\{\left(1-\tau_{p, i t}\right)\left(Y_{i t}^{j}-W_{i t} L_{i t}^{j}-\delta_{T} K_{T, i t}^{j}-X_{I, i t}^{j}-\chi_{i}^{j} X_{M, t}^{j}\right)-K_{T, i, t+1}^{j}+K_{T, i t}^{j}\right\}
$$

with $\chi_{j}^{j}=1$ and $\chi_{i}^{j}=0$ if $i \neq j$. The dividend from country $i$ is computed as the after-tax profit less retained earnings. The tax rate on profits in country $i$ is given by $\tau_{p, i}$. This tax is assessed on the taxable profit, which is equal to output $Y_{i}^{j}$ less payments to labor $L_{i}^{j}$ at rate $W_{i}$, depreciation of tangible capital $K_{T, i}^{j}$ at rate $\delta_{T}$, new investment in intangible capital $X_{I, i}^{j}$ that is specific to a location (that is, a plant in country $i$ ), and investment at home in new technology capital $X_{M}^{j}$ that, when accumulated, is intangible capital that can be used simultaneously in multiple locations across the globe. When computing profits, investments in tangible capital are treated as capital expenditures, implying that the firm subtracts only the depreciation allowance, whereas investments in the two intangible capitals are treated as expenses and therefore fully subtracted. This differential treatment, in turn, implies that retained earnings recorded by the accountants are net investment in tangible capital, which is given by $K_{T, i, t+1}^{j}-K_{T, i t}^{j}$ between period $t$ and $t+1$.

In each period $t$, output produced by multinationals from $j$ in country $i$ is given by

$$
\begin{aligned}
& Y_{i t}^{j}=A_{i t} \sigma_{i t}^{j}\left(q_{i t}^{j} M_{i t}^{j} N_{i t}\right)^{\phi}\left(Z_{i t}^{j}\right)^{1-\phi} \\
& Z_{i t}^{j}=\left(K_{T, i t}^{j}\right)^{\alpha_{T}}\left(K_{I, i t}^{j}\right)^{\alpha_{I}}\left(L_{i t}^{j}\right)^{1-\alpha_{T}-\alpha_{I}},
\end{aligned}
$$

which is the production function derived by aggregating across plants and across companies. This aggregate production function depends on the host country's total factor productivity denoted by $A_{i t}$ and its degree of openness to FDI denoted by $\sigma_{i t}^{j}$, which is equal to 1 if $j=i$ and $\sigma_{i t} \in[0,1)$ if $j \neq i$. We view the TFP and openness parameters as government policies taken as given by multinationals when deciding how much FDI to do in country $i$. Given these policies, multinationals in $j$ choose how much of available technology capital $M_{i}^{j}$ to deploy in country $i$. The stock 
of technology capital can be used nonrivalrously, but it is indexed by the FDI host country $i$, since FDI host countries differ in their quid pro quo policies; companies may have less available technology capital to use in countries that require quid pro quo than in countries that do not if technology transfers have already taken place. Furthermore, because of quid pro quo requirements, we assume that countries may choose to deploy less technology capital than is available. At the aggregate level, the fraction of technology capital deployed in country $i$ by companies in $j$ is denoted $q_{i}^{j}$ - which we refer to as the intensity level - and the total effective stock of technology capital is therefore $q_{i}^{j} M_{i}^{j}$, with $q_{i}^{j} \in[0,1]$ and $q_{i}^{i}=1$. Country $i$ has a total of $N_{i}$ locations in which to operate, and like TFP and FDI openness, we treat this as a characteristic of the country that is taken as given by multinationals. The rivalrous factors of production appear in the composite input $Z_{i}^{j}$, namely, tangible capital $K_{T, i}^{j}$, intangible capital that is location specific $K_{I, i}^{j}$, and the labor input $L_{i}^{j}$. If there are decreasing returns to the rival factors at the plant level, then companies choose to split these factors evenly across available locations $\left(N_{i}\right)$.

The first innovation of our model, relative to McGrattan and Prescott $(2009,2010)$, is that firms can choose to deploy their technology capital or not, location by location. McGrattan and Prescott abstract from quid pro quo, and multinationals in their model would choose to deploy all available technology capital, that is, $q_{i}^{j}=1$ for all $i, j$. Furthermore, if no technology capital is transferred via quid pro quo arrangements, the technology capital available is the same for all FDI host countries, that is, $M_{i}^{j}$ is the same for all $i$.

The second innovation of our model is to incorporate quid pro quo policy. When a multinational from $j$ deploys technology capital at $i$ at time $t$ at intensity $q_{i t}^{j}$, a share $h_{i t}^{j}\left(q_{i t}^{j}\right) \in[0,1]$ of the technology capital must be transferred to a local firm (the appropriator). We assume that the function $h_{i t}^{j}(\cdot)$ is weakly increasing in the intensity choice $q_{i t}^{j}$. This captures the terms of the quid pro quo - the more technology capital brought in, the greater the required transfer. If $h_{i t}^{j}\left(q_{i t}^{j}\right)$ is equal to zero for all $i, j$, and $t$, then $M_{i t}^{j}=M_{t}^{j}$ does not depend on the host country as in the McGrattan-Prescott model. In the general case, note that the property rights being transferred are specific to the destination country $i$, an assumption that we motivated earlier with the patent data. The convexity assumption captures the idea that a firm might be able to get away with transferring small (perhaps less important) ideas when the request for market access is low, protecting the most advanced and important ideas (sometimes called the "crown jewels") by keeping them at home. Large market access, however, might come only at the price of the crown jewels. ${ }^{31}$

31 An alternative structure that would produce similar results would have a proportional quid pro quo tax and curvature in the decision problem through a location-level setup cost that is convex in the intensity choice. 
The third innovation of our model is to incorporate knowledge spillovers, which we represent by the function $g\left(\mu_{t}^{j}\right)$ and model as an externality lowering the cost of technology capital investment. The argument $\mu_{t}^{j}$ is the total stock of technology capital in country $j$ at the time that multinationals decide how much to invest in new technology capital. Knowledge spillovers are not chosen by firms, but rather are taken as given when solving their maximization problem.

The quid pro quo and spillovers show up in the accumulation equation for technology capital implying an asymmetry between the location-specific capital and the nonrivalrous capital. More specifically, the capital accumulation equations for the multinational are as follows:

$$
\begin{aligned}
K_{T, i, t+1}^{j} & =\left(1-\delta_{T}\right) K_{T, i t}^{j}+X_{T, i t}^{j} \\
K_{I, i, t+1}^{j} & =\left(1-\delta_{I}\right) K_{T, i t}^{j}+X_{I, i t}^{j} \\
M_{i, t+1}^{j} & =\left(1-\delta_{M}\right)\left(1-h_{i t}^{j}\left(q_{i t}^{j}\right)\right) M_{i t}^{j}+g\left(\mu_{t}^{j}\right) X_{M, t}^{j} .
\end{aligned}
$$

The capital accumulation equations are constraints on the optimization problem, and the first two are standard. ${ }^{32}$ The third accumulation equation includes additional terms for the quid pro quo transfers and the knowledge spillovers. The first term on the right-hand side is undepreciated capital less technology transfers, and the second term is the new technology capital that includes the spillover component. The greater the technology capital being used in production in country $j$, the cheaper it is for domestic firms to create new technology capital themselves.

In sum, the new elements here relative to the framework of McGrattan and Prescott (2009, 2010) are the choice of intensity level $q_{i}^{j}$, the quid pro quo, $h_{i}^{j}(\cdot)$, and the spillovers, $g(\cdot)$. Another novelty is the incorporation of two types of firms: those that invest in technology capital and those that use transferred technology capital. We turn next to the optimization problem of the latter.

\subsection{Appropriators Problem}

Appropriators also maximize the present after-tax discounted stream of dividends. Dividends accruing to the transferred technology capital are given by

$$
\tilde{D}_{i t}=\left(1-\tau_{p, i t}\right)\left(\tilde{Y}_{i t}-W_{i t} \tilde{L}_{i t}-\delta_{T} \tilde{K}_{T, i t}-\tilde{X}_{I, i t}\right)-\tilde{K}_{T, i, t+1}+\tilde{K}_{T, i t} .
$$

32 For some parameterizations of our model, nonnegativity constraints bind for investments, especially initial investment of technology capital of countries that obtain capital through quid pro quo. To prevent nonnegative investments, we include a small subsidy for investment in technology capital when levels fall close to zero. We also include adjustment costs to avoid large initial changes in investment along the transition path. The subsidy and costs are chosen to be as small as possible to avoid violating the constraints. See Holmes, McGrattan, and Prescott (2013b) for details. 
and are distributed to households in country $i$. The relevant inputs in this case are the profits tax rate $\tau_{p i}$, output $\tilde{Y}_{i}$, payments to labor $\tilde{L}_{i}$ at wage rate $W_{i}$, depreciation of tangible capital $\tilde{K}_{T, i}$ at rate $\delta_{T}$, and new investment in plant-specific intangible capital $\tilde{X}_{I, i}$. The output produced is as follows:

$$
\begin{aligned}
& \tilde{Y}_{i t}=A_{i t}\left(\tilde{M}_{i t} N_{i t}\right)^{\phi}\left(\tilde{Z}_{i t}\right)^{1-\phi} \\
& \tilde{Z}_{i t}=\left(\tilde{K}_{T, i t}\right)^{\alpha_{T}}\left(\tilde{K}_{I, i t}\right)^{\alpha_{I}}\left(\tilde{L}_{i t}\right)^{1-\alpha_{T}-\alpha_{I}} .
\end{aligned}
$$

Notice that, unlike the multinationals with proprietary capital, the appropriator firm does not invest in new technology capital.

The maximization of after-tax dividends is subject to constraints on capital as follows:

$$
\begin{aligned}
\tilde{K}_{T, i, t+1} & =\left(1-\delta_{T}\right) \tilde{K}_{T, i, t+1}+\tilde{X}_{T, i, t+1} \\
\tilde{K}_{I, i, t+1} & =\left(1-\delta_{I}\right) \tilde{K}_{I, i, t+1}+\tilde{X}_{I, i, t+1} \\
\tilde{M}_{i, t+1} & =\left(1-\delta_{M}\right) \tilde{M}_{i t}+\sum_{j}\left(1-\delta_{M}\right) h_{i t}^{j}\left(q_{i t}^{j}\right) M_{i t}^{j} .
\end{aligned}
$$

We call the technology capital $\tilde{M}_{i}$ owned by appropriators transferred capital. Notice that appropriators do not make new investments but rather are the recipients of technology capital from others. The transferred capital, however, is included in the total stock for country $j$, which is equal to

$$
\mu_{t}^{j}=\left\{M_{j t}^{j}+\tilde{M}_{j t}+\sigma_{j t}^{\frac{1}{\phi}} \sum_{\ell \neq j} q_{j t}^{\ell} M_{j t}^{\ell}\right\} /\left(1+\gamma_{Y}\right)^{t},
$$

where $\gamma_{Y}$ is the trend growth rate of output. As we noted earlier, this total stock of technology capital is the argument of the spillover function, that is, $g\left(\mu_{t}^{j}\right)$, which is increasing in $\mu_{t}^{j}$.

\subsection{Household Problem}

Households choose sequences of consumption $C_{i t}$, labor $L_{i t}$, and assets $B_{i t+1}$ to solve the following problem:

$$
\max \sum_{t} \beta^{t}\left[\log \left(C_{i t} / N_{i t}\right)+\psi \log \left(1-L_{i t} / N_{i t}\right)\right] N_{i t}
$$

subject to

$$
\sum_{t} p_{t}\left[C_{i t}+B_{i, t+1}-B_{i t}\right] \leq \sum_{t} p_{t}\left[\left(1-\tau_{l, i t}\right) W_{i t} L_{i t}+\left(1-\tau_{d t}\right)\left(D_{t}^{i}+\tilde{D}_{i t}\right)+r_{b t} B_{i t}+\kappa_{i t}\right]
$$


where $\tau_{l i}$ and $\tau_{d}$ are tax rates on labor and company distributions, $r_{b}$ is the after-tax return on international borrowing and lending, $N_{i t}$ is the population in country $i$, and $\kappa_{i t}$ is exogenously determined income, which includes both government transfers and nonbusiness net income. ${ }^{33} \mathrm{We}$ include nonbusiness net income because we want to match accounts of the model to accounts in the data and, therefore, want to distinguish value-added and investment from business and nonbusiness sectors. We also include nonbusiness labor as part of the total labor input, and this too is exogenously set. Public consumption is included with $C_{i}$.

Notice that in specifying utility (4.7), we use the notation $N_{i t}$ for population, which is also our notation for the number of production locations in country $i$. We are assuming that the measure of a country's production locations is proportional to its population. Without loss of generality, we set the constant of proportionality equal to one.

\subsection{Market Clearing}

The worldwide resource constraint is

$$
\begin{aligned}
\sum_{i}\left\{C_{i t}\right. & \left.+\sum_{j}\left(X_{T, i t}^{j}+X_{I, i t}^{j}\right)+X_{M, t}^{i}+\tilde{X}_{T, i t}+\tilde{X}_{I, i t}+\bar{X}_{n b, i t}\right\} \\
= & \sum_{i, j} Y_{i t}^{j}+\sum_{i}\left(\tilde{Y}_{i t}+\bar{Y}_{n b, i t}\right)
\end{aligned}
$$

which is the market-clearing condition for the goods market that includes nonbusiness output $\bar{Y}_{n b, i t}$ and nonbusiness investment $\bar{X}_{n b, i t}$. Recall that these are components of nonbusiness net income for households, which is included in $\kappa_{i t}$ in (4.8).

Market clearing in asset markets occurs if $\sum_{i} B_{i t}=0$, and market clearing in labor markets occurs if

$$
L_{i t}=\sum_{j} L_{i t}^{j}+\tilde{L}_{i t}+\bar{L}_{n b, i t}, \quad i=1, \ldots, I,
$$

where $L_{i t}^{j}$ is the labor input for multinationals from $j$ operating in country $i, \tilde{L}_{i t}$ is the labor input of appropriators in country $i$, and $\bar{L}_{n b, i t}$ is the time devoted to nonbusiness work.

\subsection{Accounting Measures}

In order to compare our theory with national and international data, we first need to construct the same accounting statistics for our model that are produced for the national accounts and the

33 In our later application, we assume that some countries face borrowing constraints and impose these constraints when computing equilibria. 
balance of payments. In particular, for our quantitative analysis, we need GDP, inward FDI, and outward FDI.

GDP may be computed in two ways: by summing products or by summing incomes. For country $i$, summing products yields

$$
\mathrm{GDP}_{i t}=C_{i t}+\sum_{j} X_{T, i t}^{j}+\tilde{X}_{T, i t}+\bar{X}_{n b, i t}+N X_{i t}
$$

where $N X_{i t}$ is net exports of goods and services by country $i$. Notice that intangible investments are not included here because they are expensed and thus not part of value-added.

If GDP is found by summing incomes, we add together wages $W_{i} L_{i}$, total before-tax profits of multinationals with proprietary capital operating in the country $\sum_{j}\left(Y_{i}^{j}-W_{i} L_{i}^{j}-\delta_{T} K_{T, i}^{j}-X_{I, i}^{j}\right)-$ $X_{M}^{i}$, total before-tax profits of appropriators $\tilde{Y}_{i}-W_{i} \tilde{L}_{i}-\delta_{T} \tilde{K}_{T, i}-\tilde{X}_{I, i}$, tangible depreciation of

all businesses $\sum_{j} \delta_{T} K_{T, i}^{j}+\delta_{T} \tilde{K}_{T, i}$, and capital income less investment for the nonbusiness sector: $\bar{Y}_{n b, i}-W_{i} \bar{L}_{n b, i}-\bar{X}_{n b, i}$ :

$$
\mathrm{GDP}_{i t}=\sum_{j} Y_{i t}^{j}+\tilde{Y}_{i t}+\bar{Y}_{n b, i t}-\sum_{j} X_{I, i t}^{j}-X_{M, t}^{i}-\tilde{X}_{I, i t}
$$

In equilibrium, it must be the case that the right-hand side of (4.10) equals the right-hand side of (4.11). Equating the two and summing across countries yields the worldwide resource constraint in (4.9).

Inward and outward FDI are items in the financial accounts of the balance of payments. For the model, the financial account for country $i$ is

$$
\mathrm{FA}_{i t}=\sum_{l \neq i}\left(K_{T, l, t+1}^{i}-K_{T, l t}^{i}\right)-\sum_{l \neq i}\left(K_{T, i, t+1}^{l}-K_{T, i t}^{l}\right)+B_{i t+1}-B_{i t}
$$

where the first term is FDI by multinationals from $i$ operating abroad (outward FDI), the second term is the negative of new investment by foreigners operating in $i$ (inward FDI), and the third term is new portfolio acquisitions by households from $i$. For the accounts to balance, the financial account has to equal the current account, which is the sum of net exports and net factor payments (receipts less payments). Net factor payments are the sum of dividends, retained earnings, and interest income from abroad net of similar payments to other countries.

\section{A Multicountry Application}

We now use our theory to quantify the impact of quid pro quo on innovation, growth, and welfare. The period of analysis is 1990-2010, and, as we noted earlier, the country groupings used in this 
study are a combined entity of China and its provinces of Hong Kong, Taiwan, and Macao, the United States, Western Europe, Japan, a combined entity consisting of Brazil, Russia, and India (BRI), and a combined entity of other countries that do significant FDI in China, which we refer to as rest of world. ${ }^{34}$ We compare versions of the model with and without quid pro quo and spillovers. The models are parameterized, with inputs chosen to generate empirically plausible national and international accounts, and then simulated. We find that predictions for capital flows and innovative activity are significantly affected; adding quid pro quo leads to a much better alignment of theory and data. We then conduct welfare analysis, considering the direct and indirect effects of quid pro quo policy.

\subsection{Model Parameters}

Here, we describe our strategy for parameterizing the models. (Further details-including the specific inputs and sources of the data - are provided in Appendix A.)

We assume that countries differ in levels of TFP $\left(A_{i t}\right)$, the degree of FDI openness $\left(\sigma_{i t}\right)$, the quid pro quo policy $\left(h_{i t}^{j}\left(q_{i t}^{j}\right)\right)$, total populations $\left(N_{i t}\right)$, and tax policies related to business profits $\left(\tau_{p i}\right) .{ }^{35}$ In all other respects, they are assumed to be the same and, therefore, we use common parameters for household preferences $(\beta, \psi)$, trend growth in TFP $\left(1+\gamma_{A}\right)^{t}$, trend growth in population $\left(1+\gamma_{N}\right)^{t}$, income shares $\left(\phi, \alpha_{T}, \alpha_{I}\right)$, nonbusiness activities $\left(\bar{L}_{n b}, \bar{X}_{n b} / \mathrm{GDP}, \bar{Y}_{n b} / \mathrm{GDP}\right)$, depreciation rates $\left(\delta_{M}, \delta_{T}, \delta_{I}\right)$, and tax rates on individual incomes $\left(\tau_{l}, \tau_{d}\right)$. Specifically, we use estimates from McGrattan and Prescott's (2010) study of the U.S. current account. (See Appendix A and, in particular, Table A1.)

We have data on country populations and business tax rates, but we have to estimate values for country TFPs, degrees of openness, quid pro quo policies, and knowledge spillovers (see Appendix A for estimates of country populations and tax rates). We set the paths for the levels of TFP $A_{i t}$ and the degree of openness $\sigma_{i t}$ in order to align the trends in the model GDPs and inward FDI flows defined in Section 4.5 with their empirical analogues. ${ }^{36}$ This step amounts to finding

34 We choose 1990 as our starting point because it is before the significant rise in Chinese inward FDI. We include BRI as a comparison to China and its provinces because there are many similarities between them in 1990 . For details on country groupings, see note 24 .

35 We also assume differences in policies related to portfolio flow restrictions because some of the countries in our sample still have tight capital controls on portfolio investments. Specifically, for the benchmark models, we assume that portfolio flows are completely free in the United States, Western Europe, and Japan and completely restricted elsewhere. As a check on this assumption we consider an alternative benchmark model with free portfolio flows across all countries. See Prasad and Wei (2007) for a nice survey of capital controls in China.

36 Here, we do not model domestic policies that led to improvements in the technology parameters $A_{i t}$ - which 
trends for 12 series of inputs in order to match trends in 12 series of outputs. Note that the values for country populations and tax rates do not depend on whether we include quid pro quo and spillovers; however, levels of TFP, the degree of openness, and quid pro quo costs do depend on the inclusion.

When we allow for technology transfers, we also have to set the policy parameters for quid pro quo and spillovers. For our benchmark model, we assume that there is no quid pro quo on inward FDI to the United States, Western Europe, Japan, and the rest of world. There is quid pro quo in China and BRI where intellectual property rights are weak. For the benchmark simulation, we also assume that China and BRI impose quid pro quo on each other, but the quantitative results are little affected without this assumption. That leaves rest of world as the region that can do FDI in China and BRI without worrying about quid pro quo. We motivated this assumption earlier in Table 2. Since we do not have bilateral flows for BRI, we use the same cost function in China and BRI and parameterize it so that the share of inward FDI coming from the advanced countries - the United States, Western Europe, and Japan - to China and its provinces is aligned in the model and the data. This adds one more time series input and output. For knowledge spillovers, we set $g(\mu)=\mu^{\theta}$, with the elasticity $\theta$ equal to 0.05 . This choice is consistent with evidence in Ciccone and Hall (1996). (See Appendix A for more details on the parameter estimates.)

The results of the procedure to match the trends in GDPs and FDI flows are reported in Appendix A. The model inputs are summarized in Tables A3-A5 and the matched outputs are displayed in Figures A1-A3. Table A3 shows the paths of TFPs, $\left\{A_{i t}\right\}$, for selected years; we find little difference between the estimates of TFPs for the two versions of the model: both show that China is an outlier with respect to TFP growth. Table A4 shows the paths of the openness parameters, $\left\{\sigma_{i t}\right\}$, which do differ to some extent between the versions of the model because policies related to openness and quid pro quo both affect inward FDI flows. Table A5 shows the equilibrium intensity levels for FDI into China and BRI and the level and derivatives of the quid pro quo policy functions evaluated at these equilibrium intensity levels. The costs start out small and rise over the sample with the rise in returns to technology capital deployed in China and BRI. For example, for the technologically advanced countries investing in China, the equilibrium technology transfer rate is 0.2 percent per year in 1990 , and the rate rises to 4.5 percent per year by 2010 . We have not

may include policies related to greater openness - but rather we treat these policies as exogenous. See Hsieh and Klenow (2009) and Song, Storesletten, and Zilibotti (2011), who investigate policies affecting growth in China's productivity. 
modeled the choice of policy by the Chinese government, but it is intuitive that the vast expansion of the Chinese market gives it more bargaining power.

The implied GDPs and FDI inflows are shown in Figures A1-A3. ${ }^{37}$ Figure A1 shows the fit of the benchmark model with quid pro quo and spillovers to trends in real per capita GDP relative to real per capita GDP in the United States. Figure A2 shows the fit of the benchmark model to trends in cumulative inward FDI relative to trend GDP, which we normalize to be 1 for China in 2010. We cumulate the FDI flows because year-to-year fluctuations in these flows are large for some countries. In the case of China, for example, the cumulative FDI is the cumulative sum of inward FDI flows shown in Figure 1. We divide each country's cumulative inflow by the country's trend GDP — which is the country's own GDP in 1990 times the growth trend - to highlight that inward FDI in countries like China is growing faster than in other regions even with the Caribbean inflows excluded. Finally, Figure A3 shows the fit of the benchmark model to the share of inward FDI coming from the advanced countries to China. The data series in Figure A3 is derived by taking the ratio of inward FDI from advanced nations in Figure 1 and dividing by the total inward FDI.

The key parameters in our analysis are the terms of quid pro quo. To get some sense of the plausibility of our parameter estimates, we return to the patent data from the automobile industry shown in Table 1. Consider two alternative scenarios. The first alternative is that the 1,078 $(=936+142)$ patents granted to the Chinese joint venture firms - either owned outright or shared-represent technology transfer from the multinationals, as part of the quid pro quo for market access. If these 1,078 patents represented true original ideas, our expectation would be that these companies would be able to obtain patents on the ideas elsewhere around the world. As we demonstrated earlier, however, this is not the case (see Table 1). The second scenario assumes that patents held by the independent Chinese firms also represent technology transfer. Independent firms may claim ideas of the multinational firms as their own. If the multinationals complain - or sue as in the case of GM versus Chery - they might lose their market access; that is, acquiescence on the part of the multinationals may be part of the quid pro quo arrangement. In this case, the patent count is $4,355(=1,078+3,277)$. Further transfer also occurs with license agreements of the existing 14,500 patents, and thus the estimates of quid pro quo costs that we derive below can be thought of as lower bounds.

We can use the patent counts along with the model to infer estimates of quid pro quo in China,

37 An analogous set of pictures can be produced for Figures A1-A2 in the case of the model without quid pro quo or spillovers. 
which we denote here by $h_{c}\left(q_{c}\right)$. Let $\sum_{j \neq c} M_{c t}^{j}$ be the total foreign multinational technology capital in China at time $t$, and let $\sum_{j \neq c} p_{c t}^{j}$ be the number of new patents at time $t$ of the multinationals. Assuming a proportional factor $\xi$ between Chinese patents and foreign investment in technology capital, the stock of multinational technology capital evolves according to

$$
\sum_{j} M_{c, t+1}^{j}=\left(1-\delta_{M}\right)\left(1-h_{c}\left(q_{c}\right)\right) \sum_{j} M_{c t}^{j}+\xi \sum_{j} p_{c t}^{j}
$$

Note that, here, we are assuming that $q_{c}$ is the same for all foreign multinationals in China, and we are abstracting from knowledge spillovers. The technology capital transferred in period $t$ equals

$$
\xi p_{c t}^{T}=\left(1-\delta_{M}\right) h_{c}\left(q_{c}\right) \sum_{j} M_{c t}^{j}
$$

where the above patent count includes only joint venture patents in the first alternative and all Chinese automobile firm patents in the second. In a stationary equilibrium $\sum_{j} M_{c t}^{j}$ grows at the rate of total output $\gamma_{Y}$. Solving out for patent counts and taking ratios yields

$$
\frac{p_{c t}^{T}}{\sum_{j} p_{c t}^{j}}=\frac{\left(1-\delta_{M}\right) h_{c}\left(q_{c}\right)}{1+\gamma_{Y}-\left(1-\delta_{M}\right)\left(1-h_{c}\left(q_{c}\right)\right)} .
$$

Substituting in the ratios of patent counts and estimates that we use in the model for the depreciation rate $\delta_{M}=0.08$, and the growth rate of output $\gamma_{Y}=0.03$, we can back out $h_{c}\left(q_{c}\right)$. If we treat all joint venture patents as transferred, whereas independent firm patents are not, then the ratio of patent counts is $1,078 / 14,500$, and our estimate of the quid pro quo cost is $h_{c}\left(q_{c}\right)=0.01$. If the transferred patents include both joint venture and independent firm patents, then the ratio of patent counts is $4,355 / 14,500$, and the estimate of the quid pro quo cost is $h_{c}\left(q_{c}\right)=0.051$. These rough calculations using the patent data yield a range of estimates that brackets the estimates in Table A5 in 1995 and beyond for the equilibrium quid pro quo cost.

As a further check on our model parameterization, we later conduct a sensitivity analysis and compare the main results of our benchmark model with results for variations on the benchmark.

\subsection{Technology Capital Transfers}

We now use the model to study the impact of China's quid pro quo policy over the period 19902010 on innovation in China and the transfer of technology capital to China. We find that adding quid pro quo significantly changes the theoretical predictions and better accounts for China's low outward FDI flows. ${ }^{38}$

38 In our sensitivity analysis, we show that adding knowledge spillovers has only a small effect on the results. 
In Table 4 we report the model predictions for country shares of the world's accumulated proprietary technology capital $\left(M_{i}^{i} / \sum_{i} M_{i}^{i}\right)$, first in the benchmark model with quid pro quo and spillovers and then again in the model without these technology transfers included. With transfers, we see that China lags behind all other countries including BRI. The model predicts that in 1990, China has almost no technology capital. By 2010, its world share of proprietary technology capital has risen, but only to 5.9 percent. Although the United States, Western Europe, and Japan do lose some ground over the period, they account for more than 70 percent of world technology capital in 2010 .

When we abstract from quid pro quo and spillovers, we find that the model predictions change significantly, with China's share of world proprietary technology capital surpassing that of Japan by 2000 and coming close to that of the United States and Western Europe by 2010. In this case, China's share is close to 20 percent, which is larger than in the benchmark model by more than a factor of 3 .

To understand why the predictions for the proprietary capital shares are so different for the two versions of the model, we compare the ratios of proprietary and transferred capital stocks to GDP for the quid pro quo countries China and BRI in the benchmark model. The ratios are displayed in Table 5. For both regions, the ratio of transferred capital to GDP is much larger than the ratio of proprietary capital to GDP. In 1990, technology capital transfer to China is roughly one times GDP from foreigners doing FDI in China. This ratio falls with the rapid growth in China's GDP, but by 2010 the transferred capital stock is still large relative to the capital accumulated by Chinese multinationals, by roughly a factor of 3 (or $0.45 / 0.16$ ). The trends in these ratios are less dramatic in BRI because these countries did not grow as rapidly as China over the period. BRI's transferred capital stock is 0.61 in 1990 and falls to 0.39 in 2010.

Having first looked at levels of technology capital owned by China and BRI in Table 5, we next examine the two margins affecting inflows of technology capital into China and BRI from the advanced countries. The first margin is the intensity margin $q$ shown in the first and third columns of Table 6 . Without the quid pro quo tax, firms set $q=1$. With quid pro quo, firms from the advanced countries set $q$ substantially less then one in all years. This intensity level increases and then decreases. For example, in the case of FDI in China, the intensity level increases from 0.23 to 0.43 , over the years 1990 to 2000 , reflecting the growth in productivity that increases the incentives to bring in technology capital. The decline from 0.43 to 0.35 over the period 2000-2010 
stems from the increase in the quid pro quo tax schedule, which is consistent with the time pattern of the share of inflows to China from the advanced countries.

A second margin at play - the extensive margin - is the volume of technology capital of advanced countries that is not yet transferred. In the second and fourth columns of Table 6, we report the share of technology capital that is not yet transferred, that is, $\sum_{j} M_{i t}^{j} /\left(\tilde{M}_{i t}+\sum_{j} M_{i t}^{j}\right)$, where the $j$ in the sums are the United States, Western Europe, and Japan, and $i$ is either China or BRI. This is a measure of the share of knowledge that foreign firms still have available for use in China or BRI, which, along with the intensive margin, is a key determinant of FDI flows. Note, in particular, the results in the second column of Table 6. The share of technology capital not transferred from advanced countries to China fell from 86 percent to 77 percent between 2000 and 2010, a decline of 9 percentage points. This reflects the cumulative effect of transfers taking place over the decade. Thus the cumulative transfer channel is a significant part of the story of what happened to inflows from the advanced nations to China over the period, working in the same direction as the intensity channel. The same is true for BRI.

As an external check of the benchmark model, we consider its implications for cumulated outward flows from China, which should be relatively small if quid pro quo agreements prevent China from taking transferred capital abroad. In Figure 3 we display cumulative outward FDI relative to trend GDP for the data and the two versions of the model. The outward FDI series is constructed in an analogous way to the inward FDI series that we fit (see Figure A2). It is the ratio of cumulated FDI from China - in particular, the cumulation of flows shown in Figure 2 - relative to trend GDP, where trend GDP is China's GDP in 1990 times the growth trend. The series for the model and data are normalized by China's cumulative inward FDI relative to trend GDP in 2010. In 2010, China's cumulated outward FDI was roughly 40 percent of the cumulated inward FDI. The model without quid pro quo or spillovers predicts this statistic to be larger than 200 percent in 2010 , overpredicting outflows by a factor of 5 . In contrast, in the benchmark model the predicted value is 50 percent, which is still higher than the actual level of 40 percent, but the overprediction is small relative to what we found in the model without quid pro quo or spillovers. ${ }^{39}$

39 Both versions of the model predict that bilateral outward flows from China are roughly proportional to GDPs in recipient countries, which leads to an overprediction of the fraction of China's outflows that go to technologically advanced countries. Adding a preferential bias for goods from countries in similar income groups as in Fajgelbaum et al. (2011) would help in this dimension. 


\subsection{Policy Analysis}

We turn next to policy analysis, and examine the effects of quid pro quo policy. We consider the direct effect of quid pro quo policy by comparing our benchmark economy with an alternative in which quid pro quo arrangements are prohibited in China starting in 1990 (that is, $h_{\text {China,t }}^{j}(q)=0$, $t \geq 1990$, for all $j$ ). We consider the indirect effects of quid pro quo policy by examining the impact of other policies in two versions of the model: one with quid pro quo and spillovers included and one without. We find both the direct and indirect effects to be large.

The main results of our policy analysis are summarized in Table 7. Panel A of the table shows results for the benchmark model with quid pro quo and spillovers. In the first row, we report the welfare gains of the quid pro quo policy. Our measure of welfare is the percentage increase in the path of consumption necessary for the household to be indifferent between two economies, namely, the benchmark with the policy as it was in China and the alternative with quid pro quo prohibited in China starting in 1990. The state variables as of 1990 are the same under the two regimes, and we compare transitions. The comparison shows that China benefits substantially from its use of quid pro quo, because the policy delivers a gain of 4.5 percent of consumption, compared with the alternative scenario without quid pro quo. China's gain comes at the expense of all the other countries. The technologically advanced countries, namely the United States, Western Europe, and Japan, all lose at a rate approximately equal to a half percent of consumption. Quid pro quo works like a China-imposed tax on these countries.

In the second row of Panel A in Table 7, we report the proprietary capital ratio, defined as the 2010 benchmark level of the technology capital stock available to firms in their home country, namely, $M_{i}^{i}$ for all $i$, relative to the stock under the alternative policy. We condition on the stock in the home country because domestic firms do not face quid pro quo. Notice that, because of quid pro quo, the ratios in the advanced economies fall at the rate of 5 percent or more. The effective tax of quid pro quo decreases the incentive to invest. If China were a small share of the world economy, it would represent only a small share of potential profit for a new idea, and hence would be irrelevant for the investment decisions of foreign multinationals. By 2010, however, China's economy is large enough that its policies do matter for the advanced countries. For ROW, China's quid pro quo policy only impacts this entity indirectly; ROW is not required to exchange technology capital for market access in China but is affected slightly if levels of technology capital fall in the advanced countries. In contrast, BRI ends up being the biggest loser measured in percentage of consumption across all country groups. To see why, recall that BRI also uses quid 
pro quo. When China imposes quid pro quo, and the advanced countries cut back on technology capital investment, the BRI countries have less technology capital to appropriate.

For China and BRI, we also report the ratio of transferred capital in the benchmark and the alternative. Under the alternative policy, China has the transferred capital that it received before quid pro quo is prohibited. In the benchmark, where China uses its actual quid pro policy, it obtains a significant increase in transferred capital. In contrast, the proprietary ratio for China falls by less than half. Thus, because of the policy, China chooses technology transfers for its own investment in building up the stock of domestic-owned (indigenous) technology capital.

In addition to quantifying the direct effect of quid pro quo policy, we quantify the indirect effect of this policy by comparing the impact of other policies in the benchmark model and in the model with no quid pro quo or spillovers. Specifically, we examine the impact of greater FDI openness in China, which occurs by increasing $\sigma_{C h i n a, t}$, and the impact of improved TFP in China, which occurs by increasing $A_{\text {China,t }}$. We report the welfare gain of China's actual policies - with increasing paths for $\sigma$ and $A$-relative to baseline scenarios with the openness and TFP parameters fixed at their 1990 levels, respectively. The results for the benchmark model are summarized in Table 7, rows 4 through 7 . The results for the alternative, which is essentially the McGrattanPrescott model without quid pro quo or spillovers, are summarized in rows 8 through 11.

Consider first the effects of greater openness to FDI in China, which turn out to be very different in the two models. We see in Panel A of Table 7 that welfare is lower in China under its actual policy of greater openness between 1990 and 2010 when compared with the alternative with the openness parameter fixed; the loss is on the order of 0.5 percent per year of consumption. In contrast, all other countries gain from China's greater openness. This outcome is analogous to what happens if China gets rid of quid pro quo, which would be the case shown in the first row of Table 7 with signs flipped. To see why these experiments are similar, recall equation (4.1) for output and observe that if $\sigma$ is increased, the intensity choice $q$ can be reduced to keep total output fixed. As the quid pro quo payment is lower with lower $q$, an increase in $\sigma$ effectively allows firms to lower their quid pro quo tax bill, and China - as tax collector - is worse off. On the other hand, in the McGrattan-Prescott model without quid pro quo or spillovers (shown in Panel B), greater openness to FDI in China is always welfare improving for all countries, including China. The gain is 0.65 percent per year for China and on the order of 0.1 percent for other countries, a win-win outcome.

Predictions for the impact on innovative activity also differ, as can be seen by comparing the 
results in Panel A with Panel B. The prediction of the benchmark model is that China does more investment in technology capital as it opens to FDI, whereas the opposite is true in the model without quid pro quo or spillovers. For the benchmark, the proprietary capital stock is 4 percent higher under China's actual policy regime relative to the alternative with no change in openness. When quid pro quo and spillovers are excluded, the model predicts that the stock is 5 percent lower. If there is no quid pro quo, the increase in $\sigma$ leads to an increase in available foreign technology capital in China, and this reduces China's incentive to invest in technology capital itself. If there is quid pro quo and the increase in China's openness implies a fall in the quid pro quo payment, then there is less capital transferred and a greater incentive to invest in technology capital.

Table 7 also reports results for the impact of higher TFP in China. Specifically, we compare transition paths with TFP growing as it did over the period 1990-2010 with those in which TFP is fixed at its 1990 level. Model predictions for the welfare gains to China of higher TFP growthwhether we include or exclude technology transfers - are huge: 64 percent in the benchmark model and 70 percent in the model without quid pro quo or spillovers. With the exception of BRI, the predicted gains for other countries are modest. For BRI, the predicted gains are higher-roughly 0.8 percent per year in the benchmark model-because they gain from quid pro quo arrangements with the Chinese; the prediction is much lower, roughly 0.1 percent, in the model without quid pro quo or spillovers. Adding quid pro quo and spillovers also significantly impacts the predictions for the proprietary capital ratios. For example, in the benchmark model, China's proprietary capital with higher TFP is 84 times as large as it is when TFP is fixed at its 1990 level. The ratio is large because proprietary technology capital in 2010 is roughly zero in the counterfactual case that TFP stays fixed at a level well below that of all other countries. In this case, China appropriates the capital from foreigners. Without quid pro quo or spillovers, the model predicts that China's proprietary capital with higher TFP is only 4 times as large as it is when TFP is fixed at its 1990 level.

Overall, we find large direct effects of quid pro quo policy and large indirect effects of quid pro quo policy when considering other policy changes.

\subsection{Sensitivity Analysis}

In Table 8, we investigate the sensitivity of our main results for China as we vary the benchmark model with quid pro quo and spillovers included. In each case, we choose levels of TFPs, degrees of openness, and quid pro quo to match trends in country-relative GDPs and inward FDIs as 
discussed in Appendix A. In all cases, we reconfirm the main finding from the benchmark model, namely, that China's quid pro quo policy had a significant impact on the transfer of technology and welfare. ${ }^{40}$

In the first experiment, we abstract from knowledge spillovers that occur through FDI. In this case, $g(\mu)=1$ for all countries. The results are shown in the second column of Table 8, which should be compared with the benchmark results in the first column. There is little difference between the models with and without spillovers, except in the total amount of innovation in China. ${ }^{41}$ Without the externalities, the price of investing in technology capital is effectively higher, both inside and outside of China. Therefore, there is little change in where innovation occurs, only in how much. Ratios of technology capital to GDP are lower, but welfare calculations are barely affected.

The second experiment holds quid pro quo policy fixed, so that the function $h_{i t}^{j}(\cdot)$ is fixed over time. In this case, the model cannot generate as dramatic a decline in the share of FDI to China from advanced countries as it does in the benchmark model. Here, the fall is only 50 percent by 2010 (see Figure A3). Although the quid pro quo policy function is fixed, realized quid pro quo transfers still rise significantly over the sample period because the benefits to FDI - evidenced by increasing returns to investing in China - rise along with TFP in China. In the benchmark model, the quid pro quo costs for advanced countries doing FDI in China are 0.2 percent in 1990 and rise to 4.5 percent (see Table A5). In the model with quid pro quo policy fixed, these costs start at 0.2 percent and rise to 3.2 percent by 2010 . With less quid pro quo in 2010 , there is more innovation in China, greater outward FDI, and lower welfare gains because of China's quid pro quo policy as evidenced by comparing the third and first columns of Table 8. The differences in magnitudes, however, are quantitatively small.

In the next three experiments, we check on several assumptions concerning country categorizations and characteristics. The first concerns our categorization of Korea. In the benchmark model, Korea was included with ROW. Here, we combine Korea and Japan. The motivation for this alternative is the rise of Korean company participation in high-technology industries. As in the case of other country groupings, we subtract any FDI flows between the two countries. The results are displayed in column 4 of Table 8. When Korea is included with advanced countries, the share of FDI into China from advanced countries is slightly higher. To match the FDI inflows

40 See Holmes, McGrattan, and Prescott (2013b) for two additional experiments - one with unrestricted portfolio flows and another with a lower elasticity for the quid pro quo function $h_{i t}^{j}(q)$.

41 Despite many theoretical and empirical attempts, quantifying knowledge spillovers remains a challenge. See, for example, Atkeson and Burstein (2011), Bloom, Schankerman, and Van Reenen (forthcoming), and research surveyed by Hale and Long (2012). 
we have to lower the quid pro quo costs, which in turn implies more innovation in China and smaller gains because of the quid pro quo policy. The differences in results for China, however, are quantitatively small, since Korea is a relatively small country.

Another check on country characteristics concerns our modeling of the rest of world. In the benchmark model, we assume that China and BRI do not require transfers of technology capital from ROW. We justified this asymmetrical treatment of ROW and the advanced countries by the fact that an increasing amount of inward FDI to China is from ROW rather than the advanced countries. In this case, we redo the analysis without ROW as a check to see whether including ROW in the analysis plays a significant quantitative role for technology transfers from the advanced countries to China and BRI. ${ }^{42}$ The results for this five-country version of the model are summarized in column 5 of Table 8 . We find quantitatively small differences in these two versions of the model.

The experiment with U.K. islands included assumes that net inflows from BVI and Cayman Islands - two major sources of Chinese inward FDI - are actually FDI from the advanced countries. In the benchmark model, we excluded flows from BVI and the Cayman Islands, which we treated simply as round-tripping on the part of Chinese multinationals (see Xiao 2004 and Sutherland and Matthews 2009). Since these Caribbean nations do not report bilateral flows, there is no way to determine if part of the FDI is actually from elsewhere. Therefore, in this alternative benchmark model, we assume any net inflows from the islands, which are calculated as inward FDI less outward FDI, are actually from the advanced countries. The shares attributed to the United States, Western Europe, and Japan are equal to the shares of their reported inflows to China. The results are displayed in column 6 of Table 8 . There is not a significant difference in results between the benchmark model and this alternative, even though the gross inflows from the Caribbean islands are large. The main reason is that the net inflows are not that large, which suggests that round-tripping may well be an important factor for China's capital flows.

In the benchmark model, we assume that tax rates on corporate profits are fixed over time. China actually lowered rates, in part to attract greater foreign investment. The last column in Table 8 shows the results if we lower the tax rate on profits in China from 33 percent to 25 percent, with most of the decline occurring after 2005 as observed. The results are nearly the same as in the benchmark model, although the model predicts a slightly higher share, namely 7.9 percent, of world propriety capital for China in 2010 because lower taxes cause an increase in productive

42 Another possibility is to allow for symmetric treatment of advanced and ROW countries by China and BRI. Since the typical ROW country is less populous and has lower TFP than the advanced countries, however, the model would predict that ROW does little or no innovation in technology, instead exploiting the technology capital of the advanced countries. 
activity in China. We view this as an upper bound because the rates of the other countries are fixed in this simulation. If we allow other country tax rates to vary as well, the model statistics would be even closer to the benchmark, since all countries in our sample have seen some fall in corporate tax rates.

Lastly, we consider a robustness exercise for our claim that the model of McGrattan and Prescott (2010) cannot fit the facts for inflows and outflows into China. We based this claim on the original specification of the model in which the openness parameter $\sigma_{i t}$ for destination $i$ is the same for all source countries $j$ at a given time period $t$. A more general model can be specified in which $\sigma_{i t}^{j}$ is indexed by the source and destination pair $(i, j)$. This generalization allows for a broader interpretation of the costs of FDI, which may be low when host countries are distant or have different languages than the source country. These country-pair specific discounts are often highlighted in the literature (see, for example, Keller and Yeaple 2013 and Ramondo and Rodríguez-Clare 2013). If we have complete freedom to set the paths $\sigma_{i t}^{j}$ for all $i, j$, and $t$ in arbitrary ways, we can fit any bilateral capital flows. To tie things down, we assume that there exists a discount $\zeta<1$ on the ability to transfer technology capital between one group of countries that are close in terms of geography or language and the remaining countries. Specifically, we replace $\sigma_{i t}$ with $\tilde{\sigma}_{i t}^{j}=\zeta \sigma_{i t}$ if $i$ and $j$ are not close and $\tilde{\sigma}_{i t}^{j}=\sigma_{i t}$ if $i$ and $j$ are close. Leaving $\zeta$ constant over time is appropriate to the extent it is based on distance and language differences that are constant over time.

In Holmes, McGrattan, and Prescott (2013b), we report the results for these experiments. In setting $\sigma_{i t}^{j}$, we assume that United States and Western Europe are close and the remaining - mostly Asian - countries are close. We also vary $\zeta$ and recalibrate parameters discussed in Section 5.1 in order to match Figures A1 and A2 as before. We show that allowing for $\zeta<1$ in the McGrattan and Prescott (2010) model makes no headway in fitting the pattern of the declining share of FDI from the technologically advanced countries into China and little headway in accounting for the low outflows of FDI from China.

To summarize, we find that our main results are robust to empirically plausible variations in the benchmark model. In all of these experiments, we find that quid pro quo is a key channel for technology capital transfer to China, low outward FDI from China, and higher welfare in China.

\section{Future Predictions for China}

In this section, we explore the model's predictions for China's per capita GDP and innovative 
activity under alternative assumptions about future policies inside and outside China. To do this, we start with the state variables in 2010 for the benchmark model with quid pro quo and knowledge spillovers. We then record statistics for China two decades later, assuming alternative scenarios for global patterns of quid pro quo policy, openness, and growth. Given how globally integrated our model world is, the main lesson we draw from these experiments is that our predictions for China, especially with regard to its rank as a technological innovator, depend critically on the policies of other countries.

The results of the experiments are summarized in Table 9. As a baseline, we run the benchmark model out to 2030 and record the statistics of interest in the first row of the table. The benchmark has TFP growth converging to U.S. levels between 2010 and 2020. In this case, the projected per capita GDP relative to that of the United States is predicted to be 20 percent in 2030. The share of technology capital investment in GDP in that year would be at an annual rate of 2.3 percent, and the share of world capital would rise to 10.5 percent.

Next, we analyze a scenario with China and BRI strengthening intellectual property protection. More specifically, we assume that quid pro quo costs are removed after 2010. The results of this experiment are shown in second row of Table 9. The main difference here relative to the benchmark path is the prediction for accumulated technology capital by 2030. The model predicts a significant increase in technology capital investment by China and a world share of 18.5 percent by 2030 . On the other hand, China's per capita GDP relative to the United States stays roughly around 20 percent.

Suppose instead that quid pro quo policy is continued and China further relaxes its capital controls to the point where $\sigma_{C h i n a, t}=0.95$. In this case, we see a dramatic fall in innovative activity in China with the technology capital investment share at 0.7 percent in 2030 and the share of world proprietary capital at 4.5 percent. These results are reminiscent of the earlier results: the quid pro quo policy and the greater FDI openness work in opposite directions. What is noteworthy is the large range of predicted capital shares. If other countries further relax restrictions on FDI, we expect a shift in innovative activity toward China, by as much as a 50 percent increase in the investment rate if Western Europe opens up to FDI. We expect little change in China's overall GDP ranking, however.

If China's growth does not converge as in the benchmark but rather continues to grow at the rate seen over the period 1990-2010, we expect that China's per capita GDP will be roughly half of the U.S. level by 2030 and its share of world technology capital will be about 40 percent 
with an annual investment to GDP ratio of 6 percent. If, on the other hand, it is another country group that starts to grow rapidly, China's per capita GDP remains at roughly 20 percent of the United States in 2030 and its innovative activity will fall. If it is BRI-another large emerging market - then China becomes the technological laggard with the investment to GDP ratio falling to 0.9 percent and the world share of technology capital falling to 4.1 percent by 2030 .

Overall, the lesson that emerges from these experiments is that with the world more interconnected than ever, policies in one country can have a large effect on the sources of innovative activity and the volume of technology transfers around the globe.

\section{Summary}

This paper assesses seemingly puzzling bilateral FDI inflows and outflows for China in light of quid pro quo policy, which makes technology capital transfer a requirement for market access. The main theoretical contribution of our paper is the development of a general equilibrium model that we used to quantify the impact of this policy on innovation, growth, and welfare. The main empirical contribution of our paper is the construction of a unique data set on Chinese patents that we used to support the key mechanisms of the model. 


\section{A. Data Sources and Model Parameters}

In this appendix, we report on our data sources and parameter estimates. All of our data and computer codes are available at our website www.minneapolisfed.org/research/sr/sr486.html.

\section{A.1. Data Sources}

There are three main sources of patent data used in the analysis of Section 3. For the published patents in China, we used data on individual patents obtained from patent searches at the State Intellectual Property Office of China (SIPO). The original data set includes all published invention and utility patents over the period 1985 to 2010 (3.6 million published patents). We restrict attention to invention patents published 2005 to 2010 (1.4 million published patents). For U.S. published patent applications, we obtained the raw text files for published U.S. patent applications at the Google Bulk Patent Download site (www.google.com/googlebooks/uspto.html). Data are provided at this site through an arrangement between Google and the U.S. Patent and Trademark Office. Applications were first published in 2000. Our data begins there and extends through 2012, and includes 3.3 million published applications. For the WIPO published patent applications, we obtained WIPO applications from patent searches at the WIPO web site (patentscope.wipo.int/search/en/search.jsf). Our data includes patent years 1999 to 2012 (1.8 million applications).

Data on the top 500 foreign affiliate sales discussed in Section 3 are provided by China's Ministry of Commerce and downloaded at www.fdi.gov.cn/pub/FDI. The files posted at our website contain the sales volumes and names of the top 500 foreign affiliates doing business in China. We used the files for 2006 and 2007. We used Google Translate to translate affiliate names.

The main data used for the analysis of our quantitative model in Section 5 are populations, GDPs, FDI flows, and estimates of profits tax rates. The source of data on country populations and GDPs is the World Bank's World Development Indicators database (World Bank 1960-2012). Specifically, we use total population (sp.pop.totl), GDP in current U.S. dollars (ny.gdp.mktp.cd), and GDP at purchasing power parity in constant 2005 international dollars (ny.gdp.pcap.pp.kd). ${ }^{43}$

Several sources are used for foreign direct investments. For China, data on inward FDI (actually utilized) are available for the period 1990-2010 by source country from the China Statistical Yearbook (China National Bureau of Statistics 1990-2012). Outward FDI data by host country are available starting in 2003 from the China Commerce Yearbook (China Ministry of Commerce 2003-2012). Prior to 2003, we use total FDI flows reported by the United Nations in their UNCTADstat and China's 2003 outward FDI stocks to estimate the bilateral flows. Specifically, we construct pro rata shares of the total flow, with the shares equal to the ratio of a host country's stock in 2003 relative to the total outward FDI stock from China.

To construct FDI for China, we include inward and outward flows to and from the provinces of Hong Kong, Macao, and Taiwan and subtract out any flows between the provinces. Hong Kong's

43 The WDI does not publish data for Taiwan and has missing years for some countries. We use the International Monetary Fund's World Economic Outlook Database (IMF 1990-2012) and the United Nation's National Accounts Main Aggregates Database (UN 1990-2012) to fill in the missing data. 
Census and Statistics Department publishes data on inward FDI by major investor country and outward FDI by major recipient. The data are available starting in 1997. As with China, we use stocks for the first year data are available and total FDI flows from UNCTAD to construct estimates for the pre-1997 bilateral flows. As before, the estimates are found by multiplying the total flow reported by UNCTAD by the ratio of a country's stock of FDI in 1997 to the total stock. We do this for flows in and out of Hong Kong. Macao's Statistics and Census Service publishes bilateral FDI statistics starting in 2001. The flows and stocks are small relative to the other Chinese provinces, especially at the start, and therefore we simply assume they are zero for the period 1990-2000. Taiwan does not report bilateral flows. Where available, we use statistics of bilateral FDI flows to and from Taiwan reported by other countries, and we use UNCTAD data for Taiwan's FDI totals.

For OECD countries other than the United States, we use FDI statistics, which are available for their partner countries, reported to the OECD by member countries (see OECD 1990-2010). As in the case of China, we subtract out any FDI flows between the European countries when constructing FDI statistics for Western Europe. The United States data come directly from the U.S. Bureau of Economic Analysis because there is typically a lag in reporting revised data to the OECD.

We do not have all bilateral flows for the combined entities BRI or ROW, but do have total inward flows. The source of the total inward flows is UNCTADstat. Without bilateral flows, it is not possible to subtract out flows to and from countries within a group of countries. Instead, we construct population-weighted ratios of FDI to GDP, which we interpret as the typical ratio for countries in that group. Then, to get total FDI flows, we multiply the weighted ratio by total GDP for the group.

The main source of data for tax rates on profits is the OECD Tax Database (OECD 19902012). For non-OECD countries, we use estimates compiled by the accounting firm KPMG (19932012). For our benchmark simulations, we hold the rates fixed at their 1990 levels, which are equal to 38.6, 42.9, 50, 32.9, 35, and 32.1 for the United States, Western Europe, Japan, China, BRI, and ROW, respectively. ${ }^{44}$

\section{A.2. Model Parameters}

Next, we provide details on our models' parameter estimates. We consider two versions of the model, without and with quid pro quo and spillovers. The model without these factors has $g\left(\mu^{j}\right)=$ 1 for all $j$ and $h_{i}^{j}\left(q_{i}^{j}\right)=0$ for all $i, j$. The model with them has $g\left(\mu^{j}\right)>1$ for all $j$ and $h_{i}^{j}\left(q_{i}^{j}\right)>0$ for a subset of $i, j$ pairs.

The parameters that are common across the two versions of the model are reported in Tables A1 and A2. In Table A1, we report estimates from McGrattan and Prescott's (2010) study of the U.S. current account. These parameters, which we assume are the same in all countries, include preference parameters, trend growth rates, income shares, depreciation rates, and tax rates on

44 In our sensitivity analysis, we feed in time varying rates for China and find that our results are robust to this extension. 
labor and dividends. McGrattan and Prescott (2010) do not model the externalities $g(\mu)$. Here, for the model with quid pro quo and spillovers, we use the same functional form for the knowledge spillovers in all countries, namely, $g(\mu)=\mu^{\theta}$, with the elasticity $\theta$ equal to 0.05 . This choice is consistent with evidence in Ciccone and Hall (1996). In Table A2, we report the time path of total populations relative to the United States from the WDI. These paths are used as our measure of $\left\{N_{i t}\right\}, i=1, \ldots, 6$. After 2010, we assume the relative populations remain at the 2010 level.

The parameters that differ across countries and across versions of the model are the paths of TFPs $\left\{A_{i t}\right\}$, the paths of the degree of openness $\left\{\sigma_{i t}\right\}$, and paths for the quid pro quo cost functions $h_{i t}^{j}(\cdot)$. As we noted earlier, we choose these inputs in order to generate observed trends in per capita GDPs, inward FDIs, and inward FDI from advanced countries into China. For almost all bilateral interactions, we assume that $h_{i t}^{j}(\cdot)=0$ in all periods. The exception is FDI from the United States, Western Europe, and Japan into China and into BRI. For those transactions, we assume there are quid pro quo requirements. We also assume that China and BRI require quid pro quo transfers from each other.

Matching observed trends in GDPs and FDIs amounts to solving a system of equations, with as many parameter inputs as observations. Since we only consider matching the trends, we limit attention to smooth paths for the inputs $\left\{A_{i t}\right\}$ and $\left\{\sigma_{i t}\right\}$. For the version of the model with quid pro quo, we choose the same functional form for the quid pro quo cost, namely,

$$
h_{i t}^{j}(q)=\min \left\{\bar{h}_{t} q \exp (-\eta(1-q)), 1\right\}
$$

for all sources $j$ and for the host countries China and BRI $(i=4,5)$. This function is weakly increasing in $q$. The choice of this functional form is motivated by the fact that we need some curvature in the function (that is, $\eta>0$ ) for an interior equilibrium to exist. In our benchmark model, we set $\eta=10$ and check to make sure that the results are robust to a wide range of values for $\eta{ }^{45}$ We vary $\bar{h}_{t}$ and interpret this as a change in policy governing IP protection. A higher value of $\bar{h}_{t}$ is associated with weaker IP protection and results in higher quid pro quo costs. ${ }^{46}$

In Tables A3-A5, we report the benchmark model inputs for TFPs, openness, and quid pro quo needed to match trends in the data. ${ }^{47}$ Parameters in Table A3 are the total factor productivities $\left(A_{i t}\right)$ in the model without transfers and the model with transfers, respectively. Notice that matching the trends in the data requires a large increase in China's TFP. For Western Europe and BRI, there was little catch-up to U.S. levels and thus we have constant TFP paths. For Japan, there was actually a decline in the relative TFPs. Comparing the two versions of the model, we see that adding quid pro quo and spillovers does not have a large impact on the implied TFP parameters.

45 What matters are the paths of the equilibrium intensity levels and quid pro quo costs, which in turn determine the share of FDI coming to China from advanced countries. To match this share, we need to vary the path of $\bar{h}_{t}$ as we vary the elasticity $\eta$.

46 Section 4.5 considers variations in the benchmark model including one with fixed IP policy. In this case, with $\bar{h}_{t}$ constant, the model cannot generate the full drop in the share shown in Figure A3, but the main results are not significantly different from the benchmark; China's large rise in TFP plays a central role for the equilibrium choice of intensity level.

47 The time period of the model is annual, but since we choose the parameters to fit trends in the data, we report only selected years in the input tables. Inputs for all years are reported in Holmes, McGrattan, and Prescott (2013b). 
Table A4 shows the degree of openness parameters $\left(\sigma_{i t}\right)$ in the model without transfers and the model with transfers, respectively. The choice of these parameters is sensitive to observations on inward FDI and, in the case of China and BRI, whether we include transfers in the model. In Table A5 we report the equilibrium intensity levels and quid pro quo costs, which are more economically interpretable than the choice of $\bar{h}$ needed to align bilateral flows into China. To match the bilateral flows, we need to assume that the quid pro quo costs that foreign multinationals in China and BRI face must have grown. By the end of the sample, the costs for multinationals from the advanced countries doing FDI in China are as high as 3.6 percent annually.

In Figures A1-A3, we display the implied model outputs. We make several adjustments to GDP and FDI data to facilitate comparisons with our model analogues. First, we divide the per capita GDPs for all countries by U.S. per capita GDP; this allows us to normalize $A_{1 t}$ to 100 for all $t$ without loss of generality. Second, we cumulate the inward FDI over time because there are large fluctuations in the year-by-year investments. We then deflate these investments, which are in nominal terms, and detrend them by dividing by population and the growth trend due to technology. In order to facilitate comparison, we divide the series for cumulated FDI relative to trend by the value for China in 2010. We can construct the same time series for our model economy. We choose the paths of $A_{i t}, \sigma_{i t}, \bar{h}_{t}$, so that the trends in the model series match the trends in the data series. The results of this procedure will depend on which version of the model we are working with. Figures A1-A3 reflect the case with quid pro quo and spillovers, In the model without them, we construct analogous figures for per capita GDPs and cumulative FDI as Figures A1-A2. There is no analogue for Figure A3, since $\bar{h}_{t}=0$ for all $t$ in the model without transfers. 
Table A1

Model Parameters Common Across Countries

\begin{tabular}{lcr}
\hline \hline Parameter & Expression & Value \\
\hline Preferences & $\beta$ & .98 \\
Discount factor & $\psi$ & 1.32 \\
Leisure weight & & \\
Growth rates (\%) & $\gamma_{N}$ & 1.0 \\
Population & $\gamma_{A}$ & 1.2 \\
Technology & & 7.0 \\
Income shares (\%) & $\phi$ & 6.5 \\
Technology capital & $(1-\phi) \alpha_{T}$ & 65.1 \\
Tangible capital & $(1-\phi) \alpha_{I}$ & \\
Plant-specific intangible capital & $\phi)\left(1-\alpha_{T}-\alpha_{I}\right)$ & 6 \\
Labor & & 15 \\
Nonbusiness sector (\%) & $\bar{L}_{n b}$ & 31 \\
Fraction of time at work & $\bar{X}_{n b} / \mathrm{GDP}$ & 34 \\
Investment share & $\bar{Y}_{n b} / \mathrm{GDP}$ & 28 \\
Value-added share & & 6.0 \\
Depreciation rates (\%) & $\delta_{M}$ & 0 \\
Technology capital & $\delta_{T}$ & \\
Tangible capital & $\delta_{I}$ & \\
Plant-specific intangible capital & & \\
Tax rates (\%) & $\tau_{l}$ & \\
Labor wedge & & \\
Dividends & & \\
\hline \hline
\end{tabular}

NotE.-Parameters are taken from McGrattan and Prescott's (2010) analysis of the U.S. current account. 
TABLE A2

Populations Relative to the United States, Selected Years

\begin{tabular}{lcccccc}
\hline \hline & U.S. & W. Europe & Japan & China & BRI & ROW \\
\hline 1990 & 100 & 151 & 49 & 465 & 469 & 172 \\
1995 & 100 & 144 & 47 & 463 & 479 & 175 \\
2000 & 100 & 138 & 45 & 458 & 487 & 177 \\
2005 & 100 & 136 & 43 & 451 & 497 & 182 \\
2010 & 133 & 41 & 442 & 505 & 185 \\
\hline \hline
\end{tabular}

NOTE.-The source of these data is the World Bank, World Development Indicators database. Holmes, McGrattan, and Prescott (2013b) report all years.

TABLE A3

Total Factor Productivities Relative to United States, Selected Years

\begin{tabular}{|c|c|c|c|c|c|c|}
\hline & U.S. & W. Europe & Japan & China & BRI & ROW \\
\hline & \multicolumn{6}{|c|}{ A. Model without Quid Pro Quo or Spillovers } \\
\hline 1990 & 100 & 80.5 & 92.4 & 11.9 & 20.0 & 33.8 \\
\hline 1995 & 100 & 80.6 & 89.2 & 13.2 & 20.0 & 35.2 \\
\hline 2000 & 100 & 80.6 & 88.0 & 16.6 & 20.0 & 36.6 \\
\hline 2005 & 100 & 80.7 & 88.0 & 22.4 & 20.9 & 38.0 \\
\hline 2010 & 100 & 80.7 & 88.0 & 27.4 & 21.0 & 39.2 \\
\hline \multirow[t]{2}{*}{2015} & 100 & 80.8 & 88.0 & 29.8 & 21.0 & 40.3 \\
\hline & \multicolumn{6}{|c|}{ B. Model with Quid Pro Quo and Spillovers } \\
\hline 1990 & 100 & 80.5 & 92.4 & 13.5 & 20.0 & 34.0 \\
\hline 1995 & 100 & 80.6 & 89.2 & 16.3 & 20.0 & 35.2 \\
\hline 2000 & 100 & 80.6 & 88.0 & 20.3 & 20.1 & 36.4 \\
\hline 2005 & 100 & 80.7 & 88.0 & 24.5 & 21.5 & 37.6 \\
\hline 2010 & 100 & 80.7 & 88.0 & 27.8 & 21.7 & 38.6 \\
\hline 2015 & 100 & 80.8 & 88.0 & 29.7 & 21.7 & 39.5 \\
\hline
\end{tabular}

NOTE.-TFP parameters are chosen to align trends in data and model. See text for details and Holmes, McGrattan, and Prescott (2013b) for all years. 
TABLE A4

Degree of Openness to Foreign Direct Investment, Selected Years

\begin{tabular}{lllllll}
\hline \hline & U.S. & W. Europe & Japan & China & BRI & ROW \\
\hline & & \multicolumn{2}{l}{ A. Model } & without Quid Pro Quo or Spillovers & \\
1990 & .815 & .815 & .680 & .623 & .684 & .760 \\
1995 & .815 & .815 & .680 & .763 & .685 & .760 \\
2000 & .819 & .817 & .684 & .765 & .696 & .764 \\
2005 & .834 & .824 & .701 & .765 & .749 & .781 \\
2010 & .845 & .829 & .711 & .765 & .783 & .791 \\
2015 & .846 & .830 & .713 & .765 & .788 & .793 \\
& & & & & & \\
1990 & .849 & .852 & .689 & .667 & .654 & .775 \\
1995 & .849 & .852 & .689 & .717 & .656 & .775 \\
2000 & .852 & .853 & .693 & .794 & .679 & .780 \\
2005 & .863 & .857 & .713 & .810 & .782 & .802 \\
2010 & .871 & .860 & .726 & .812 & .850 & .817 \\
2015 & .872 & .860 & .728 & .812 & .859 & .819 \\
\hline \hline
\end{tabular}

NoTE.-Degree of openness parameters are chosen to align trends in data and model. See text for details and Holmes, McGrattan, and Prescott (2013b) for all years.

TABLE A5

Intensity Levels and Quid Pro Quo Costs, Model with Quid Pro Quo and Spillovers Selected Years

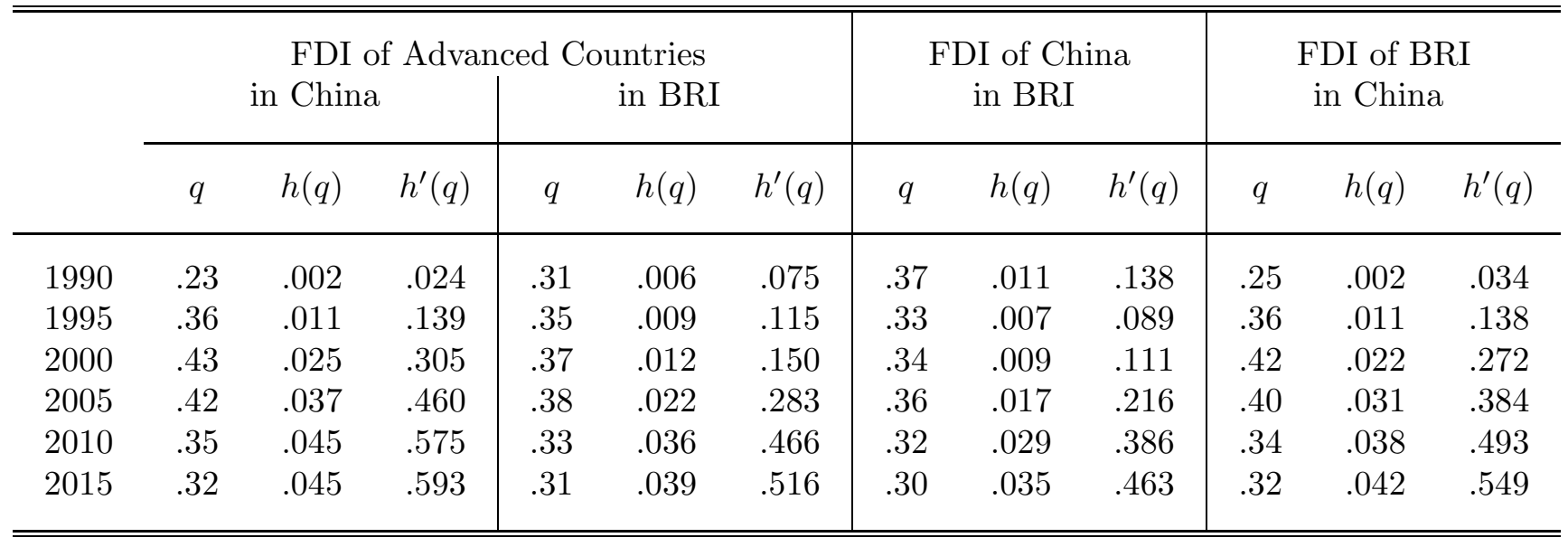

NotE.-Quid pro quo costs are chosen to align trends in data and model. Values for $q, h(q)$, and $h^{\prime}(q)$ are indexed by source and host of FDI. In equilibrium, the differences between values in the case of FDI coming from the United States, Western Europe, and Japan are less than one percent so we report only one value for China and one value for BRI. See text for details and Holmes, McGrattan, and Prescott (2013b) for all years. 
Figure A1. Real Per Capita GDP Relative to U.S.

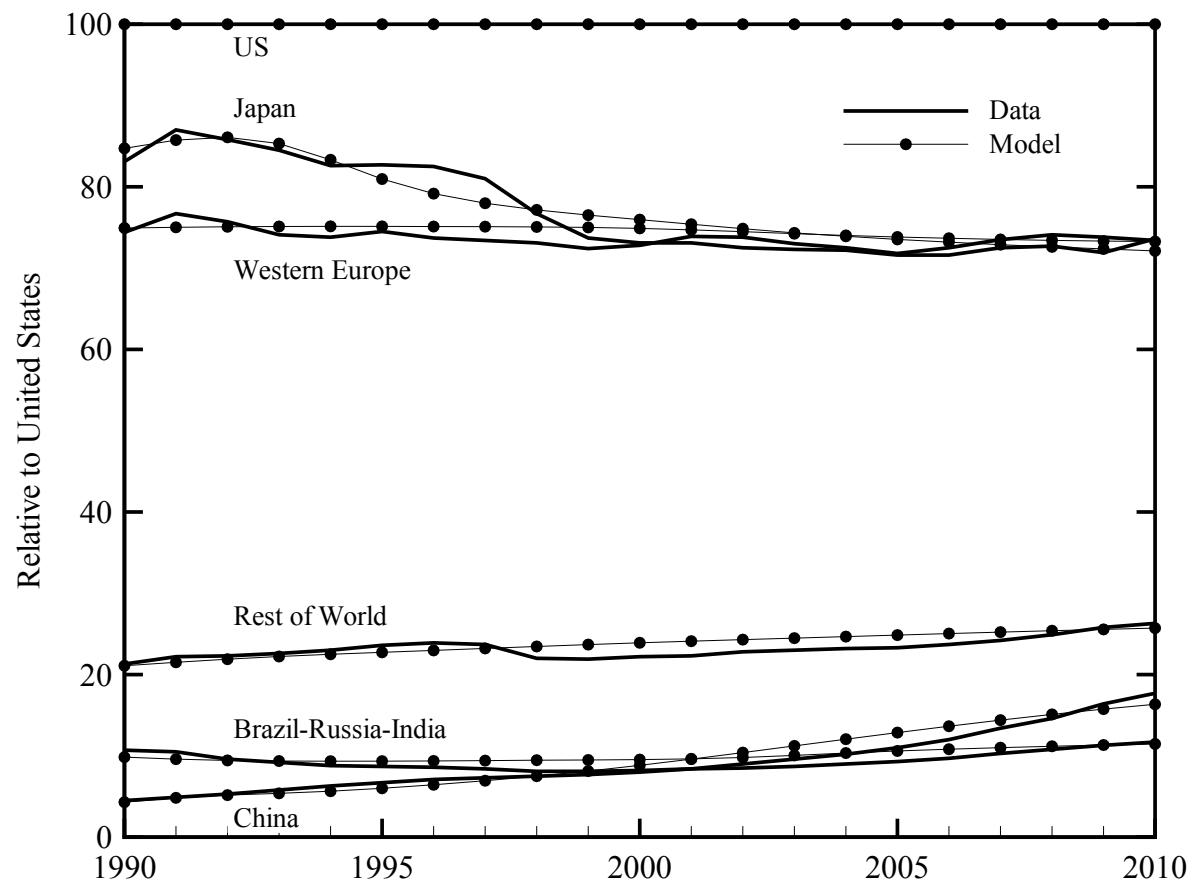

Figure A2. Cumulative Inward FDi Relative to Trend GDP, Normalized by 2010 Estimate for China




Figure A3. Share of Inward FDI to China from the United States, Western Europe, and Japan

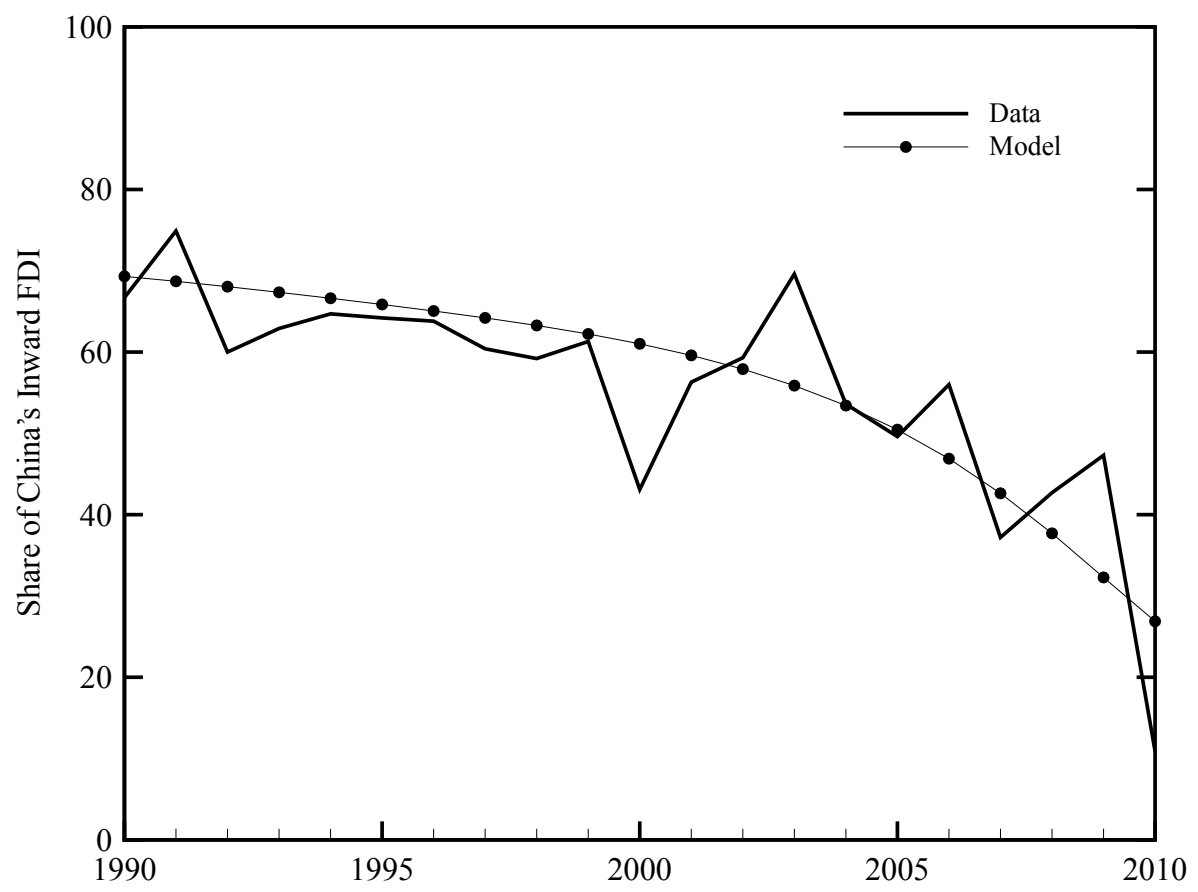




\section{References}

American Chamber of Commerce in China (AmCham China), 2013, China Business Climate Survey Report, www.amchamchina.org.

Atkeson, Andrew, and Ariel Burstein, 2011, "Aggregate Implications of Innovation Policy," Working Paper, University of California, Los Angeles.

Backus, David K., Patrick J. Kehoe, and Finn E. Kydland, 1992, "International Business Cycles," Journal of Political Economy, 100(4): 745-775.

Bloom, Nicholas, Mark Schankerman, and John Van Reenen, forthcoming, "Identifying Technology Spillovers and Product Market Rivalry," Econometrica.

Branstetter, Lee, and C. Fritz Foley, 2010, "Facts and Fallacies about U.S. FDI in China," in China's Growing Role in World Trade, edited by Robert C. Feenstra and Shang-Jin Wei (Chicago: University of Chicago Press).

Branstetter, Lee, and Nicholas Lardy, 2006, "China's Embrace of Globalization," NBER Working Paper 12373.

Branstetter, Lee, Ray Fisman, C. Fritz Foley, and Kamal Saggi, 2011, "Does Intellectual Property Rights Reform Spur Industrial Development?" Journal of International Economics, 83(1): $27-36$.

China Ministry of Commerce, 2003-2012, China Commerce Yearbook, www.yearbook.org.cn.

China Ministry of Commerce, 2007, Catalogue for the Guidance of Foreign Investment Industries, www.fdi.gov.cn.

China National Bureau of Statistics, 1990-2012, China Statistical Yearbook, www.stats.gov.cn.

China State Council, 2006, "The National Medium- and Long-Term Program for Science and Technology Development (2006-2020): An Outline," www.gov.cn.

China Supreme People's Court, 1999, Contract Law of the People's Republic of China, en.chinacourt. org.

Ciccone, Antonio, and Robert E. Hall, 1996, "Productivity and the Density of Economic Activity," American Economic Review, 86(1): 54-70.

Defever, Fabrice, and Alejandro Riaño, 2012, "China's Pure Exporter Subsidies," Working Paper, University of Nottingham.

Dernis, Hélène, and Mosahid Khan, 2004, "Triadic Patent Families Methodology," OECD Science, Technology and Industry Working Papers, OECD Publishing, www.oecd-library.org.

Eaton, Jonathan, and Samuel Kortum, 1999, "International Technology Diffusion: Theory and Measurement," International Economic Review, 40(3): 537-570. 
European Commission, 2011, "Technology Transfer to China: Guidance for Businesses," China IPR SME Help Desk, www.china-iprhelpdesk.eu.

Fajgelbaum, Pablo, Gene M. Grossman, and Elhanan Helpman, 2011, "A Linder Hypothesis for Foreign Direct Investment," NBER Working Paper 17550.

Grossman, Gene M., and Elhanan Helpman, 1991a, "Quality Ladders in the Theory of Growth," Review of Economic Studies, 58(1): 43-61.

Grossman, Gene M., and Elhanan Helpman, 1991b, "Quality Ladders and Product Cycles," Quarterly Journal of Economics, 106(2): 557-586.

Hale, Galina, and Cheryl Long, 2011, "Are There Productivity Spillovers from Foreign Direct Investment in China?" Pacific Economic Review, 16(2): 135-153.

Hale, Galina, and Cheryl Long, 2012, Foreign Direct Investment in China: Winners and Losers (Singapore: World Scientific).

Hao, Janet, 2012, "Intangible Investment in China Has Grown Rapidly-But Is It Efficient?" Chart of the Week, August 24, China Center for Economics and Business, The Conference Board.

Helpman, Elhanan, 1993. "Innovation, Imitation, and Intellectual Property Rights." Econometrica, 61(6): 1247-1280.

Helpman, Elhanan, Marc J. Melitz, and Stephen R. Yeaple, 2004, "Export Versus FDI with Heterogeneous Firms," American Economic Review, 94(1): 300-316.

Holmes, Thomas J., Ellen R. McGrattan, and Edward C. Prescott, 2013a, "Patent Data Appendix for Quid Pro Quo: Technology Capital Transfers for Market Access in China," Research Department Staff Report 488, Federal Reserve Bank of Minneapolis.

Holmes, Thomas J., Ellen R. McGrattan, and Edward C. Prescott, 2013b, "Technical Appendix for Quid Pro Quo: Technology Capital Transfers for Market Access in China," Research Department Staff Report 487, Federal Reserve Bank of Minneapolis.

Hong Kong Census and Statistics Department, 1997-2012, National Income and Balance of Payments, www. censtatd.gov.hk.

Horstmann, Ignatius J. and James R. Markusen, 1992, "Endogenous Market Structures in International Trade (Natura Facit Saltum)," Journal of International Economics, 32(1-2): 109-129.

Hsieh, Chang-Tai Hsieh, and Peter J. Klenow, 2009, "Misallocation and Manufacturing TFP in China and India," Quarterly Journal of Economics, 124(4): 1403-1448.

Hulten, Charles R., and Janet X. Hao, 2012, "The Role of Intangible Capital in the Transformation and Growth of the Chinese Economy," NBER Working Paper 18405.

International Monetary Fund (IMF), 1990-2012, World Economic Outlook Database, www.imf.org. 
Keller, Wolfgang, and Stephen R. Yeaple, 2013, "The Gravity of Knowledge," American Economic Review, 103(4): 1414-1444.

KPMG International, 1993-2012, Corporate and Indirect Tax Rate Survey, www.kpmg.com.

Lai, Edwin L.C., 1998, "International Intellectual Property Rights Protection and the Rate of Product Innovation," Journal of Development Economics, 55(1): 133-153.

Macao Statistics and Census Service, 2001-2012, Direct Investment Statistics, www.dsec.gov.mo.

Markusen, James R., 2001, "Contracts, Intellectual Property Rights, and Multinational Investment in Developing Countries," Journal of International Economics, 53(1): 189-204.

Markusen, James R., and Anthony J. Venables, 2000, "The Theory of Endowment, Intra-industry and Multi-national Trade," Journal of International Economics, 52(2): 209-234.

McGrattan, Ellen R., and Edward C. Prescott, 2009, "Openness, Technology Capital, and Development," Journal of Economic Theory, 144(6): 2454-2476.

McGrattan, Ellen R., and Edward C. Prescott, 2010, "Technology Capital and the U.S. Current Account," American Economic Review, 100(4): 1493-1522.

National Science Foundation (NSF), 2012, Science and Engineering Indicators 2012, www.nsf.gov.

Organisation for Economic Co-operation and Development (OECD), 1990-2010, "FDI Flows by Partner Country," OECD.StatExtracts, www.oecd.org.

Organisation for Economic Co-operation and Development (OECD), 1990-2012, OECD Tax Database, stats.oecd.org.

Organisation for Economic Co-operation and Development (OECD), 2000, OECD Patents by Technology, stats.oecd.org.

Prasad, Eswar and Shang-Jin Wei, 2007, "The Chinese Approach to Capital Inflows: Patterns and Possible Explanations," in Capital Controls and Capital Flows in Emerging Economies: Policies, Practices, and Consequences, edited by Sebastian Edwards, (Chicago: University of Chicago Press).

Ramondo, Natalia, Veronica Rappaport, and Kim J. Ruhl, "Horizontal versus Vertical Foreign Direct Investment: Revisiting Evidence from U.S. Multinationals," Working Paper, Arizona State University.

Ramondo, Natalia, and Andrés Rodríguez-Clare, 2013, "Trade, Multinational Production, and the Gains from Openness," Journal of Political Economy, 121(2): 273-322.

Shea, Dennis, 2012, "The Impact of International Technology Transfer on American Research and Development," Testimony: Committee on Science, Space, and Technology Subcommittee on Investigations and Oversight, December 5, United States House of Representatives. 
Song, Zheng, Kjetil Storesletten, and Fabrizio Zilibotti, 2011, "Growing Like China," American Economic Review, 101(1): 196-233.

Sutherland, Dylan, and Ben Matthews, 2009, "'Round Tripping' or 'Capital Augmenting' OFDI? Chinese Outward Investment and the Caribbean Tax Havens," Working Paper, University of Nottingham.

United Nations (UN), 1990-2012, National Accounts Main Aggregates Database, unstats.un.org.

United Nations (UN), 1990-2012, FDI Statistics Division on Investment and Enterprise, UNCTADstat, unctadstat.unctad.org.

United States International Trade Commission (USITC), 2010, "China: Intellectual Property Infringement, Indigenous Innovation Policies, and Frameworks for Measuring the Effects on the U.S. Economy," Investigation No. 332-514, USITC Publication 4199 (amended).

U.S. Congress, Office of Technology Assessment, 1987, "Technology Transfer to China," OTA-ISC340 (Washington, DC: U.S. Government Printing Office).

U.S.-China Business Council, 2012a, USCBC 2012 China Business Environment Survey Results, www.uschina.org.

U.S.-China Business Council, 2012b, USCBC 2012 China Business Environment Survey Supplement, www.uschina.org.

Van Reenen, John, and Linda Yueh, 2012, "Why Has China Grown So Fast? The Role of International Technology Transfer," Working Paper, London School of Economics.

Walsh, Kathleen A., 1999, "U.S. Commercial Technology Transfers to the People's Republic of China," A Report to the Office of Strategic Industries and Economic Security, Bureau of Export Administration, www.bis.doc.gov.

World Bank, 1960-2012, World Development Indicators, data.worldbank.org.

World Intellectual Property Organization (WIPO), 2012, World Intellectual Property Indicators, 2012 edition, www.wipo.org.

World Trade Organization (WTO), 2001, Accession of the People's Republic of China, Decision of 10 November 2001 (WT/L/432, 01-5996), www.wto.org.

Xiao, Geng, 2004, "People's Republic of China's Round-Tripping FDI: Scale, Causes and Implications," ADB Institute Discussion Paper No. 7. 


\section{Figure 1. Inward Foreign Direct Investment to China $^{a}$}

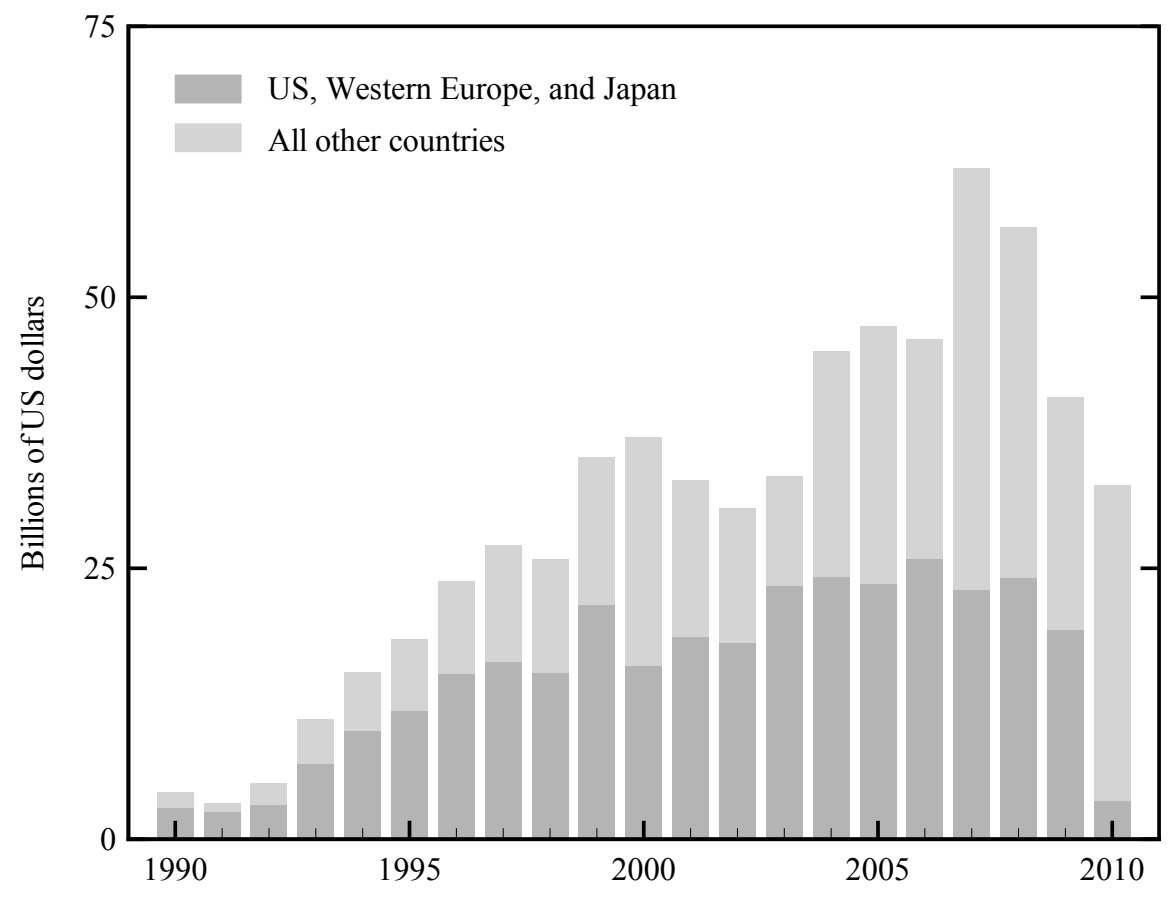

Figure 2. Outward Foreign Direct Investment from China ${ }^{a}$

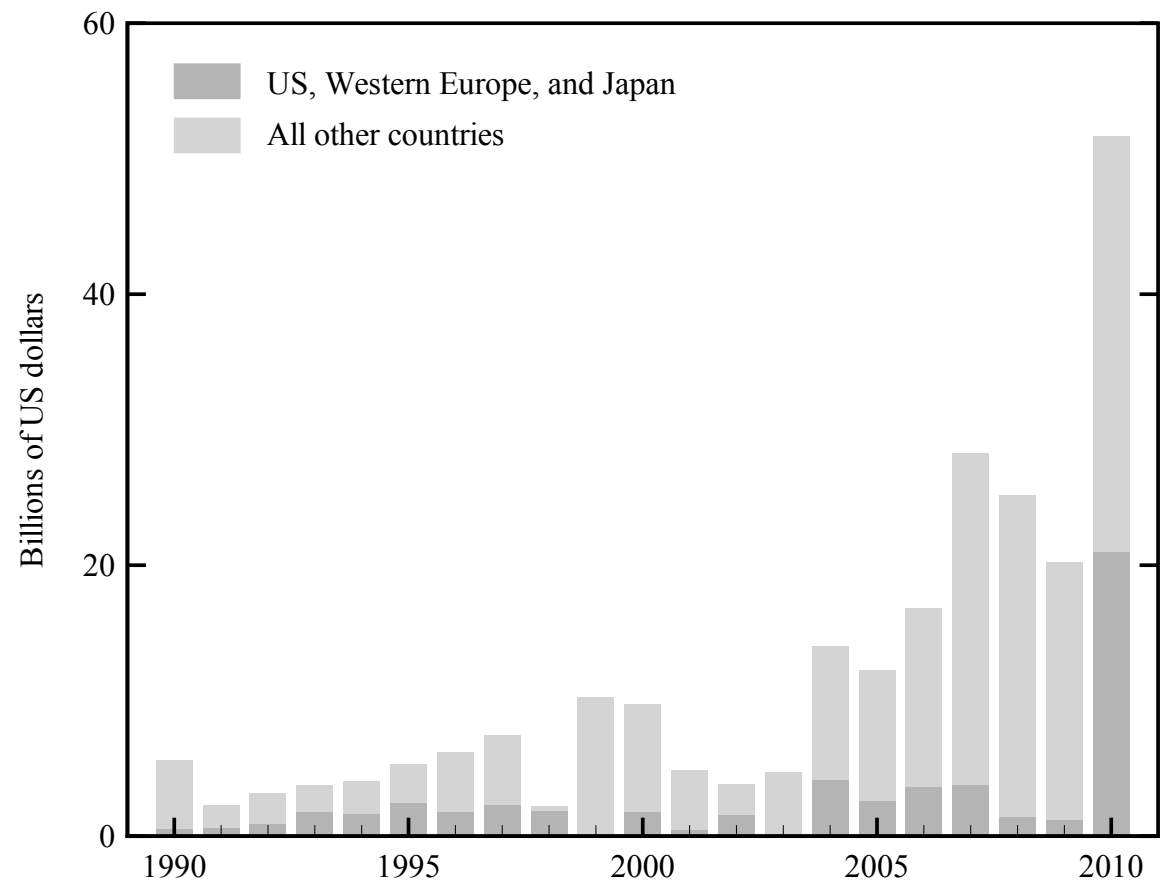

a Includes inward and outward flows to Hong Kong, Taiwan, and Macao with intraprovincial flows netted. Excludes flows to and from the British Virgin Islands and Cayman Islands. 
Figure 3. Cumulative Outward FDi Relative to Trend GDP, Normalized by 2010 Estimate of Inward FDI to China ${ }^{a}$

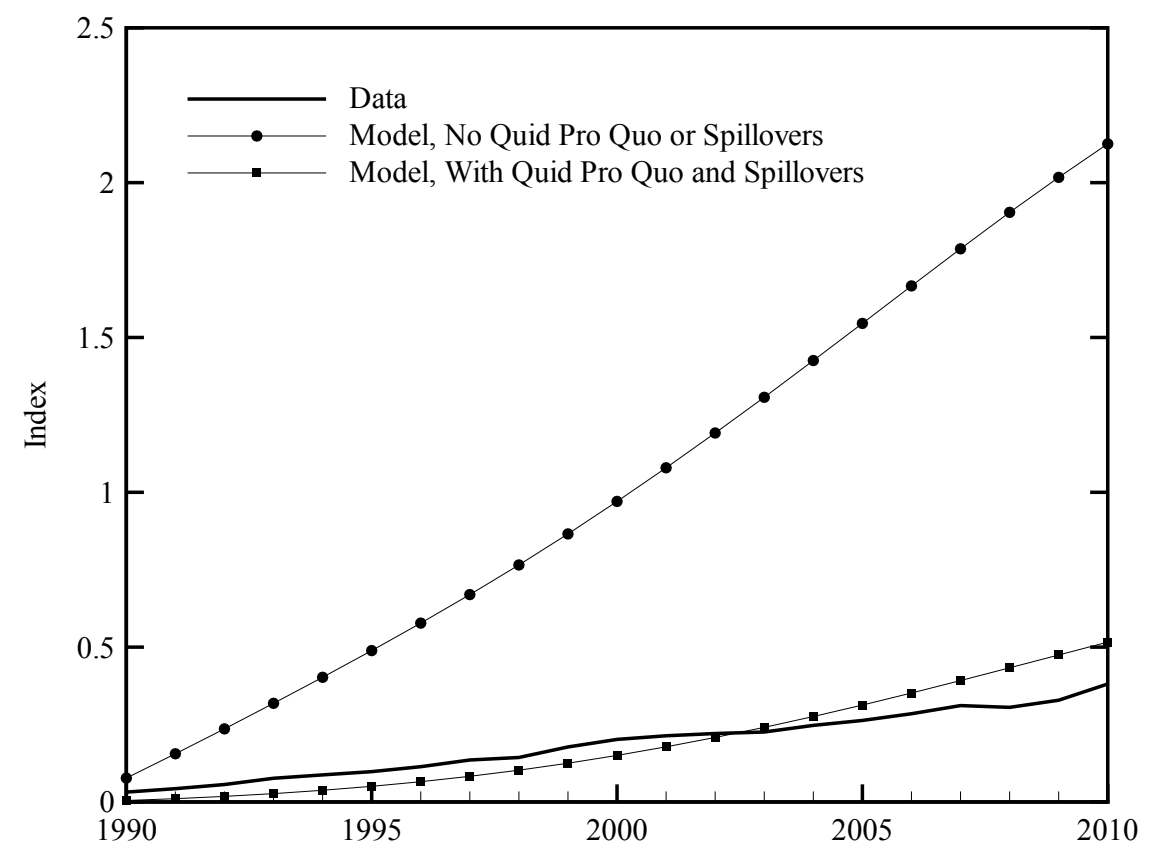

a The normalization used here is the same as for Figure A2. 
Table 1. Published Patent Applications in China for Large Foreign Multinationals and Domestic Chinese Firms, 2005-2010

\begin{tabular}{|c|c|c|}
\hline Type of Applicant & $\begin{array}{l}\text { Number of } \\
\text { Patents }\end{array}$ & $\begin{array}{l}\text { \% Linked to U.S. or } \\
\text { WIPO Application }\end{array}$ \\
\hline & \multicolumn{2}{|c|}{ A. All Industries } \\
\hline Foreign multinational & 209,594 & 82.1 \\
\hline $\begin{array}{l}\text { Shared with Chinese partners } \\
\text { Not shared }\end{array}$ & $\begin{array}{r}10,184 \\
199,410\end{array}$ & $\begin{array}{r}1.7 \\
86.2\end{array}$ \\
\hline \multicolumn{3}{|l|}{ Only patents first filed in China } \\
\hline Chinese firms & 585,650 & 4.7 \\
\hline $\begin{array}{l}\text { Top } 100 \text { domestic patenters } \\
\text { Not top } 100\end{array}$ & $\begin{array}{r}79,518 \\
506,132\end{array}$ & $\begin{array}{r}16.5 \\
2.8\end{array}$ \\
\hline \multicolumn{3}{|l|}{ Foreign multinational } \\
\hline $\begin{array}{l}\text { Shared with Chinese partners } \\
\text { Not shared }\end{array}$ & $\begin{array}{l}10,075 \\
12,446\end{array}$ & $\begin{array}{r}1.5 \\
10.1\end{array}$ \\
\hline \multicolumn{3}{|c|}{ Foreign multinational, Chinese inventor and location } \\
\hline \multirow[t]{2}{*}{ Not shared } & $\begin{array}{l}7,446 \\
2,113\end{array}$ & $\begin{array}{r}2.0 \\
10.6\end{array}$ \\
\hline & \multicolumn{2}{|c|}{ B. Automobile Industry } \\
\hline \multicolumn{3}{|l|}{ Foreign multinational } \\
\hline $\begin{array}{l}\text { Shared with Chinese partners } \\
\text { Not shared }\end{array}$ & $\begin{array}{r}142 \\
14,500\end{array}$ & $\begin{array}{r}0.7 \\
85.0\end{array}$ \\
\hline \multicolumn{3}{|l|}{ Chinese firms } \\
\hline $\begin{array}{l}\text { Joint venture } \\
\text { Independent company }\end{array}$ & $\begin{array}{r}936 \\
3,277\end{array}$ & $\begin{array}{l}0.9 \\
7.4\end{array}$ \\
\hline
\end{tabular}

Note.-Authors' calculations are based on microdata on published patents in China. Patent counts include only invention patents. See Appendix A and Holmes, McGrattan, and Prescott (2013a) for more details. 
Table 2. Indicators of High Technology for Country Groupings, 2000

\begin{tabular}{lcc}
\hline & $\begin{array}{c}\text { Number of Triadic Patents } \\
\text { Granted Annually } \\
\text { (per million in population) }\end{array}$ & $\begin{array}{c}\text { Value-Added of Knowledge- and } \\
\text { Technology-Intensive Industries } \\
\text { (as a percentage of GDP) }\end{array}$ \\
\hline \hline China & 0.1 & 20.2 \\
United States & 49.1 & 36.3 \\
Western Europe & 36.3 & 28.7 \\
Japan & 117.0 & 28.4 \\
Brazil-Russia-India & 0.1 & 19.3 \\
Rest of World & 3.5 & 24.8 \\
\hline \hline
\end{tabular}

NoTE. - Triadic patent counts are obtained from the OECD Patents by Technology database (variable: Triadic patent families). Total populations are taken from the World Development Indicators (variable: sp.pop.totl). Data on high-technology production are reported in NSF (2012, Table 6-1). These industries include knowledge-intensive services and high-technology manufacturing classified by the OECD. Knowledge-intensive services include education, health, and business, financial, and communications services. High-technology manufacturing industries include aerospace, communications and semiconductors, computers and office machinery, pharmaceuticals, and scientific instruments and measuring equipment. 
Table 3. Statistics on Income and Technology for China, Selected Years, 1990-2010

\section{China's income}

$\begin{array}{lrrr}\text { Real per capita GDP (dollars) } & 1,436 & 2,946 & 7,434 \\ \text { Share of world GDP (\%) } & 4.6 & 8.1 & 14.9\end{array}$

China's technology share $(\%)$

R\&D expenditures of U.S., EU, Japan, and China

Patents in:

China, published in year

WIPO, published in year

United States, granted to foreigners

Including Taiwan

Excluding Taiwan
54.1

n.a.

0.5

0.1
38.6

0.2

10.2

2.9

NoTE.-Real GDP is in 2005 international dollars. Sources of GDP and population data are reported in Appendix A. Data on R\&D expenditures are reported in the NSF (2012, Appendix Table 4-43). The last year available is 2009, which is our estimate of 2010. The R\&D expenditures for EU are based on the current 27 member countries, and the expenditures for China include only China and Hong Kong. China patents are published invention patents for a given year. China's share is calculated as the fraction of patents first filed in China and not claiming foreign priority from another country. For the WIPO patents, generally two sets of applicants are reported. The first set applies for the United States, and this set lists the inventors, which are considered the applicants in the U.S. system. The second set applies outside of the United States and consists of the organizations that own the patent. If the inventors retain ownership of the patent, then the inventor is listed in the second set as well. To define the nationality of a WIPO patent, we take the second set of applicants and classify the patent as from China if at least one applicant lists residence in or nationality as China. The source for U.S. patent grants is NSF (2012, Appendix Table 6-45) for years 2000 and 2010 (year 2010 data are based on the authors' calculations with the raw data). 
TABle 4

Share of World Proprietary Technology Capital (\%), Selected Years

\begin{tabular}{|c|c|c|c|c|c|c|}
\hline & China & U.S. & W. Europe & Japan & BRI & ROW \\
\hline & \multicolumn{6}{|c|}{ A. Model with Quid Pro Quo and Spillovers } \\
\hline 1990 & 0.1 & 32.1 & 37.7 & 16.4 & 2.4 & 11.3 \\
\hline 1995 & 0.6 & 31.0 & 35.5 & 15.5 & 4.7 & 12.7 \\
\hline 2000 & 2.0 & 30.0 & 33.5 & 14.2 & 6.6 & 13.7 \\
\hline 2005 & 4.1 & 28.9 & 32.0 & 13.1 & 7.3 & 14.5 \\
\hline \multirow[t]{2}{*}{2010} & 5.9 & 28.5 & 31.3 & 12.5 & 6.2 & 15.5 \\
\hline & \multicolumn{6}{|c|}{ B. Model without Quid Pro Quo or Spillovers } \\
\hline 1990 & 6.7 & 26.4 & 30.4 & 12.6 & 14.7 & 9.2 \\
\hline 1995 & 9.3 & 25.4 & 28.4 & 11.8 & 15.0 & 10.1 \\
\hline 2000 & 12.5 & 24.4 & 26.7 & 10.8 & 15.0 & 10.6 \\
\hline 2005 & 16.2 & 23.2 & 25.1 & 9.9 & 14.8 & 10.9 \\
\hline 2010 & 19.4 & 22.1 & 23.8 & 9.2 & 14.4 & 11.1 \\
\hline
\end{tabular}

NotE.-The share for country $i$ is $M_{i t}^{i} / \sum_{i} M_{i t}^{i}$. 
TABLE 5

Ratio of Technology Capital to GDP in China and Brazil-Russia-India (BRi),
Model with Quid Pro Quo and Spillovers, Selected Years

\begin{tabular}{cc|c|c|c}
\hline \hline & \multicolumn{2}{c|}{ Technology Capital of China } & \multicolumn{2}{c}{ Technology Capital of BRI } \\
\cline { 2 - 5 } & Proprietary & Transferred & Proprietary & Transferred \\
\hline & 0.00 & 1.04 & 0.09 & 0.61 \\
1990 & 0.04 & 0.73 & 0.19 & 0.45 \\
2000 & 0.09 & 0.49 & 0.26 & 0.35 \\
2005 & 0.14 & 0.44 & 0.26 & 0.31 \\
2010 & 0.16 & 0.45 & 0.21 & 0.39 \\
\hline \hline
\end{tabular}

NOTE.-The proprietary capital share for country $i$ is $M_{i t}^{i} / \mathrm{GDP}_{i t}$ and the transferred capital share is $\tilde{M}_{i t} / \mathrm{GDP}_{i t}$.

TABLE 6

Technology Capital of Advanced Countries in China and Brazil-Russia-India (BRI), Model with Quid Pro Quo and Spillovers, Selected Years

\begin{tabular}{|c|c|c|c|c|}
\hline & \multicolumn{2}{|c|}{ FDI in China } & \multicolumn{2}{|c|}{ FDI in BRI } \\
\hline & $\begin{array}{c}\text { Multinationals' } \\
\text { Intensity } \\
\text { Level }\end{array}$ & $\begin{array}{c}\text { Share of } \\
\text { Technology Capital } \\
\text { Not Transferred }\end{array}$ & $\begin{array}{c}\text { Multinationals' } \\
\text { Intensity } \\
\text { Level }\end{array}$ & $\begin{array}{c}\text { Share of } \\
\text { Technology Capital } \\
\text { Not Transferred }\end{array}$ \\
\hline 1990 & 0.23 & 0.80 & 0.31 & 0.80 \\
\hline 1995 & 0.36 & 0.86 & 0.35 & 0.86 \\
\hline 2000 & 0.43 & 0.86 & 0.37 & 0.87 \\
\hline 2005 & 0.42 & 0.82 & 0.38 & 0.83 \\
\hline 2010 & 0.35 & 0.77 & 0.33 & 0.78 \\
\hline
\end{tabular}

NOTE.-The intensity level for multinationals $j$ in country $i$ is equal to $q_{i t}^{j}$. In equilibrium, the differences between intensity levels of multinationals from the United States, Western Europe, and Japan are less than one percent so we report only one value for China and one value for BRI and refer to these as the intensity levels of the advanced countries. Technology capital not transferred is defined to be the ratio $\sum_{j} M_{i t}^{j} /\left(\tilde{M}_{i t}+\sum_{j} M_{i t}^{j}\right)$ where the sums over $j$ include only multinationals from the United States, Western Europe, and Japan. 
TABLE 7

Welfare Gains and Technology Capital Transfers, Arising from Policy Changes in China, 1990-2010

\begin{tabular}{|c|c|c|c|c|c|c|}
\hline & China & U.S. & W. Europe & Japan & BRI & ROW \\
\hline & \multicolumn{6}{|c|}{ A. Model with Quid Pro Quo and Spillovers } \\
\hline \multicolumn{7}{|l|}{ Direct effect of quid pro quo } \\
\hline Welfare gain $(\%)$ & 4.51 & -0.48 & -0.47 & -0.35 & -1.33 & -0.10 \\
\hline Proprietary capital ratio & 0.42 & 0.95 & 0.94 & 0.92 & 1.10 & 1.02 \\
\hline Transferred capital ratio & 10.3 & - & - & - & 0.89 & - \\
\hline \multicolumn{7}{|l|}{ Indirect effects of quid pro quo } \\
\hline \multicolumn{7}{|l|}{ Greater openness $\left(\sigma_{\text {China }, t}\right)$} \\
\hline Welfare gain $(\%)$ & -0.48 & 0.08 & 0.08 & 0.08 & 0.01 & 0.29 \\
\hline Proprietary capital ratio & 1.04 & 1.01 & 1.02 & 1.02 & 1.00 & 1.08 \\
\hline \multicolumn{7}{|l|}{ Higher TFP $\left(A_{C h i n a, t}\right)$} \\
\hline Welfare gain (\%) & 63.5 & 0.18 & 0.16 & 0.07 & 0.76 & 0.26 \\
\hline Proprietary capital ratio & 83.9 & 1.00 & 1.00 & 1.01 & 0.92 & 1.05 \\
\hline \multirow{2}{*}{\multicolumn{7}{|c|}{ B. Model without Quid Pro Quo or Spillovers }} \\
\hline & & & & & & \\
\hline Welfare gain $(\%)$ & 0.65 & 0.10 & 0.11 & 0.12 & 0.09 & 0.08 \\
\hline Proprietary capital ratio & 0.95 & 1.02 & 1.02 & 1.03 & 1.02 & 1.02 \\
\hline \multicolumn{7}{|l|}{ Higher TFP $\left(A_{C h i n a, t}\right)$} \\
\hline Welfare gain $(\%)$ & 70.4 & 0.23 & 0.18 & 0.07 & 0.13 & 0.17 \\
\hline Proprietary capital ratio & 4.01 & 0.97 & 0.98 & 1.00 & 0.99 & 0.98 \\
\hline
\end{tabular}

NOTE.-The welfare gains are the percentage increase in paths of consumption necessary for households in a specified country to be indifferent between having complete IP protection in China starting in 1990 versus its actual path with quid pro quo ("Direct effect of Quid Pro Quo"), between having China's degree of FDI openness remain at its 1990 level versus its actual path ("Greater openness"), or between having China's TFP remain at the 1990 level versus its actual path ("Higher TFP"). The capital ratios are ratios of the proprietary and transferred capital stocks in 2010 for each country, with the numerators equal to the stocks consistent with the policies China actually followed, and the denominators equal to the stocks consistent with the counterfactual policies. 
TABLE 8

Chinese Statistics for Variations on the Benchmark

Model With Quid Pro Quo AND SpILlovers, 1990-2010

\begin{tabular}{|c|c|c|c|c|c|c|c|}
\hline & \multirow[b]{2}{*}{$\begin{array}{l}\text { Benchmark } \\
\text { Model }\end{array}$} & \multicolumn{6}{|c|}{ Variations of the Benchmark Model } \\
\hline & & $\begin{array}{c}\text { No } \\
\text { FDI } \\
\text { Spillovers }\end{array}$ & $\begin{array}{l}\text { Fixed } \\
\text { QPQ } \\
\text { Policy }\end{array}$ & $\begin{array}{c}\text { Korea } \\
\text { with } \\
\text { Japan }\end{array}$ & $\begin{array}{l}\text { No } \\
\text { Rest of } \\
\text { World }\end{array}$ & $\begin{array}{c}\text { UK } \\
\text { Islands } \\
\text { Included }\end{array}$ & $\begin{array}{l}\text { China's } \\
\text { Tax Rate } \\
\text { Lowered }\end{array}$ \\
\hline \multicolumn{8}{|l|}{2010 Predictions for: } \\
\hline $\begin{array}{l}\% \text { Share of world } \\
\text { proprietary capital }\end{array}$ & 5.9 & 6.6 & 7.4 & 7.9 & 6.9 & 6.2 & 7.9 \\
\hline \multicolumn{8}{|l|}{ Capital-GDP ratios } \\
\hline Proprietary capital & .16 & .13 & .21 & .19 & .16 & .17 & .21 \\
\hline Transferred capital & .45 & .34 & .39 & .41 & .45 & .43 & .43 \\
\hline $\begin{array}{l}\text { Cumulated outward } \\
\text { to inward FDI }\end{array}$ & .52 & .60 & .65 & .53 & .50 & .47 & .58 \\
\hline $\begin{array}{l}\% \text { Welfare gain due to } \\
\text { quid pro quo }\end{array}$ & 4.5 & 4.6 & 3.9 & 4.1 & 4.0 & 4.1 & 4.5 \\
\hline
\end{tabular}

Note.-Results for the benchmark model are also shown in Tables 4-6 and Figure 3. The experiments are as follows: "No FDI Spillovers" has $g(\mu)=1$ for all countries; "Fixed QPQ Policy" has a quid pro quo cost function that is not time varying; "Korea with Japan" has Korea with Japan rather than ROW; "No Rest of World" includes only the five non-ROW countries; "UK Islands Included" includes net inflows to China from the UK islands with advanced country flows; and "China's Tax Rate Lowered" assumes that China's corporate profits tax rate falls from 33 percent to 25 percent, with most of the decline occurring between 2005 and 2009. The same procedure for choosing parameters in the benchmark model is applied in all variations of the benchmark. See Appendix A for details and Holmes, McGrattan, and Prescott (2013b) for a list of all parameter inputs. 
TABLE 9

Predictions for China in 2030, Alternative Future Scenarios, Model with Quid Pro Quo and Spillovers

\begin{tabular}{|c|c|c|c|}
\hline Future path: & $\begin{array}{c}\text { Per Capita GDP } \\
\text { Relative to } \\
\text { the U.S. } \\
(\%)\end{array}$ & $\begin{array}{c}\text { Investment in } \\
\text { Technology Capital } \\
\text { Relative to GDP } \\
(\%)\end{array}$ & $\begin{array}{c}\text { Share of World } \\
\text { Proprietary } \\
\text { Technology Capital } \\
(\%)\end{array}$ \\
\hline Benchmark continued & 20.0 & 2.3 & 10.5 \\
\hline Quid pro quo discontinued & 19.6 & 5.4 & 18.5 \\
\hline \multicolumn{4}{|c|}{$\begin{array}{l}\text { Quid pro quo continued and } \\
\text { openness reaches } 95 \% \text { by } 2030\end{array}$} \\
\hline In China & 20.3 & 0.7 & 4.5 \\
\hline In BRI & 19.9 & 2.3 & 10.2 \\
\hline In ROW & 19.9 & 2.4 & 10.7 \\
\hline In Western Europe & 20.0 & 3.5 & 14.5 \\
\hline In Japan & 19.7 & 2.7 & 11.9 \\
\hline In United States & 19.4 & 3.3 & 13.9 \\
\hline \multicolumn{4}{|c|}{ High TFP growth, 2010-2030 } \\
\hline In China & 50.2 & 6.0 & 39.6 \\
\hline In BRI & 20.3 & 0.9 & 4.1 \\
\hline In ROW & 19.9 & 2.2 & 7.5 \\
\hline \multicolumn{4}{|c|}{ TFP reaches U.S. level by 2030} \\
\hline In Western Europe & 19.1 & 1.8 & 7.5 \\
\hline In Japan & 19.7 & 2.2 & 10.0 \\
\hline
\end{tabular}

NoTE.-In all simulations, the state variables are taken from the benchmark simulation for the year 2010 . The "Quid prop quo discontinued" simulation assumes there are no quid pro quo transfers in any country starting in 2011. Simulations listed under "Quid pro quo continued" assume all parameters are the same as in the benchmark except the paths for TFP $A_{C h i n a, t}$ or the degree of openness $\sigma_{C h i n a, t}$. In the case of "Openness reaches $95 \%$ " and "TFP reaches U.S. level by 2030," we use gradually increasing paths for the openness and TFP parameters, respectively. For the "High TFP growth" simulations, we use the same annual growth rate in TFP between 2010 and 2030 as that used in the benchmark model for China over the period 1990-2010. All inputs for these experiments are provided in Holmes, McGrattan, and Prescott (2013b). 